Review

\title{
Environmental Citizen Science Initiatives as a Springboard towards the Education for Environmental Citizenship: A Systematic Literature Review of Empirical Research
}

\author{
Anastasia Adamou 1(D), Yiannis Georgiou 1,2(D), Demetra Paraskeva-Hadjichambi ${ }^{1,2}$ \\ and Andreas Ch. Hadjichambis $1,2, *$ (D) \\ 1 Cyprus Centre for Environmental Research and Education (CYCERE), Limassol 3304, Cyprus; \\ na.kykpee@gmail.com (A.A.); yg.kykpee@gmail.com (Y.G.); d.hadjichambi@cytanet.com.cy (D.P.-H.) \\ 2 Ministry of Education, Culture, Sport and Youth (MOECSY), Nicosia 1434, Cyprus \\ * Correspondence: a.hadjichambis@cytanet.com.cy; Tel.: +357-99477309
}

\section{check for} updates

Citation: Adamou, A.; Georgiou, Y.; Paraskeva-Hadjichambi, D.; Hadjichambis, A.C. Environmental Citizen Science Initiatives as a Springboard towards the Education for Environmental Citizenship: A Systematic Literature Review of Empirical Research. Sustainability 2021, 13, 13692. https://doi.org/ $10.3390 /$ su132413692

Academic Editor: Changwoo Ahn

Received: 2 November 2021

Accepted: 9 December 2021

Published: 11 December 2021

Publisher's Note: MDPI stays neutral with regard to jurisdictional claims in published maps and institutional affiliations.

Copyright: (c) 2021 by the authors. Licensee MDPI, Basel, Switzerland. This article is an open access article distributed under the terms and conditions of the Creative Commons Attribution (CC BY) license (https:// creativecommons.org/licenses/by/ $4.0 /)$.

\begin{abstract}
Environmental Citizen Science (CS) initiatives have been recognized over time as a promising way to engage citizens in the investigation and management of various socio-ecological issues. In this context, it has been often hypothesized that these CS initiatives may also contribute to the education and subsequent transformation of citizens into environmentally aware and active citizens. However, the potential of CS to serve as a springboard for supporting Education for Environmental Citizenship (EEC) has not been explored yet. A systematic review was conducted, seeking to examine how citizens' participation in environmental CS initiatives contributes to the EEC, as a venue through which citizens can undertake actions in different scales (local, national, global) to achieve environmental citizenship. A content analysis procedure was implemented on thirty-one empirical studies $(n=31)$ retrieved from a systematic review of the literature covering the timespan of the last two decades (2000-2020), according to the PRISMA methodology. The findings indicated that the majority of the reviewed environmental CS initiatives primarily enhanced citizens' skills and knowledge over the competences of attitudes, values, and behaviors. In addition, it was found that CS initiatives empowered primarily citizens' personal and responsible environmental actions, which were situated in the private sphere and at the local scale. The derived environmental outcomes were mainly related to the solution and prevention of environmental problems. Finally, correlational statistical analysis indicated that there were strong correlations between the Environmental Citizenship (EC) competences, actions and EEC outcomes and unveiled a set of keystone components; namely, components of crucial significance in the field of EC. We reflect on these findings, and we discuss directions for future research.
\end{abstract}

Keywords: Education for Environmental Citizenship (EEC); EC actions; EC competences; EEC outcomes; environmental citizen science (CS) initiatives; systematic literature review

\section{Introduction}

The world is facing an unprecedented global environmental crisis, as environmental problems have been exacerbated in recent decades. Climate change and the consequent degradation of ecosystems, biodiversity loss, as well as the depletion and degradation of natural resources, are among the most prevalent socio-ecological challenges our planet is dealing with [1]. Inevitably, human well-being does not remain unaffected by this drastic pace of change, as nature and humans are closely connected, thus urgent actions are required to be taken. In view of the growing pressure on nature, scientists have often argued towards the involvement of citizens in environmental Citizen Science (CS) initiatives, as a way to contribute to environmental management and ecological conservation.

The term "Citizen Science" was first coined in the mid-1990s by Irwin (1995) [2]. It refers to the involvement of citizens, hereafter citizens, in the scientific process [3,4], with 
the aim of examining scientific questions and addressing issues of common concern [5] in the fields of science, policy, and society [6]. Over the past decade, CS has gained prominence as a tool for science and public engagement, and especially in ecological and environmental science $[7,8]$. CS benefits both science and the environment, as it serves as an effective key tool in environmental research $[9,10]$, and as a key component in monitoring progress towards addressing various socio-ecological issues $[8,11]$. The development of environmental CS initiatives constitutes a valuable contribution to the scientific realm, as it provides an understanding of ecological processes towards conservation planning and environmental management [7,12]. These could be attributed to the CS affordances on collecting large datasets with environmental data due to the input of citizens; these datasets are then deployed to understand and address various socio-ecological challenges.

Although CS is well documented for its benefits to science and the scientific community $[13,14]$, more broadly, it can also be valuable to society, as it can facilitate knowledge generation, empower individuals and communities, stimulate action-taking, and enhance civic participation in commons and in decision-making processes [8,15]. This process of developing an ever-increasing awareness can be also seen as an effective form of education that supports environmental and social awareness efforts [8]. Put simply, environmental CS initiatives are assumed to have the potential to strengthen social ties with science and nature as well as to raise global environmental awareness based on the notion of environmental rights and responsibilities, by providing a promising venue which can support Education for Environmental Citizenship (EEC) [16]. In this way, environmental CS initiatives may act as a springboard towards EEC which empowers citizens to act as "agents of change", who are actively involved in civic engagement and participation to tackle current and future socio-ecological problems and challenges [17].

However, despite the assumed benefits of participation in environmental CS, it is important to note that not all environmental CS initiatives are intended to promote environmental citizenship, as many of them are deliberately designed to address merely scientific questions [16]. More specifically, environmental CS initiatives often adopt a more scienceoriented rather than a citizen-centered approach [18]. Despite the fact, the extent to which CS initiatives achieve to promote environmental citizenship remains unexplored. In this paper, we focus on CS initiatives which have an environmental management and ecological conservation focus, with the ultimate goal to investigate whether and how environmental CS initiatives contribute to Education for Environmental Citizenship (EEC). Put simply, as part this review, we sought to investigate the impact of the reviewed CS initiatives on citizens' environmental citizenship, to define the potential relations of the EC components identified in the CS initiatives as well as to find out the more salient EC components.

\section{Theoretical Framework}

Environmental Citizenship (EC) is a multifaceted concept, which deals with proenvironmental behavior and citizens' attitudes towards environmental conservation and social change. Tsybulsky (2020) strongly argues that EC is manifested in terms of proenvironmental behavior with a positive change on citizens' attitudes towards the environment [19]. In this line, environmental citizens could be actively involved with the commons while integrating pro-environmental actions to tackle current and emerging socio-ecological problems.

A recent work undertaken by the European Network for Environmental Citizenship (https: / / enec-cost.eu/, accessed on 30 August 2020) (ENEC 2018) comprehensively conceptualizes EC as follows:

"Environmental Citizenship is defined as the responsible pro-environmental behavior of citizens who act and participate in society as agents of change in the private and public sphere on a local, national and global scale, through individual and collective actions in the direction of solving contemporary environmental problems, preventing the creation of new environmental problems, achieving sustainability and developing a healthy relationship with nature. 'Environmental 
Citizenship' includes the practise of environmental rights and duties, as well as the identification of the underlying structural causes of environmental degradation and environmental problems and the development of the willingness and the competences for critical and active engagement and civic participation to address those structural causes and to act individually and collectively within democratic means, taking into account inter- and intra-generational justice."

This conceptualization of EC has been widely used in the literature since 2018 [16,18,20,21]. Grounded in this definition, the ultimate goal of Education for Environmental Citizenship (EEC) is to equip citizens with a coherent corpus of competences that will enable them to act pro-environmentally, as "agents of change", as well as to help them understand the urgency of current socio-ecological issues and realize the necessity to actively participate in the civic and social arena. Towards this direction, Hadjichambis and ParaskevaHadjichambi (2020), in their recent work undertaken within ENEC, proposed the EEC model that paves the way to promote EC in an integrated educational approach [17]. In this model, the scholars summarized the structural elements of EEC as follows: (a) the competences that shape citizen's personal development, (b) the potential actions an environmental citizen may undertake (in different dimensions, spheres, scales), and (c) the main intended environmental outcomes that could contribute to environmental and social change. An overview of the model is illustrated in Figure 1.

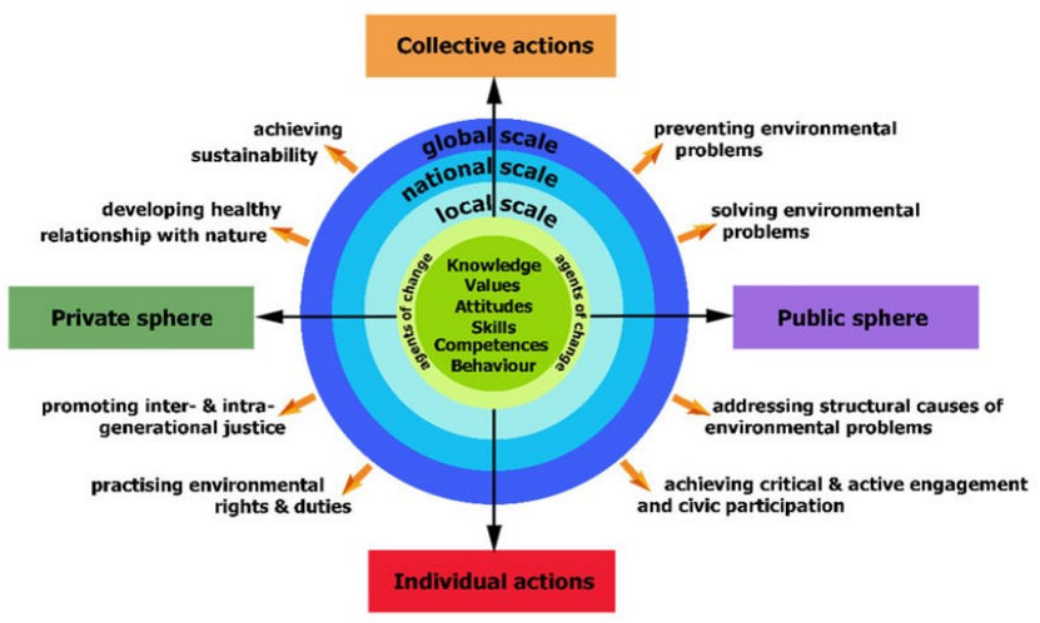

Figure 1. The EEC Model [17].

What follows in the next subsections is a brief overview of the structural components comprising the EEC model.

\subsection{The EC Competences}

The EC competences (presented within the green cycle of Figure 1) constitute the adequate body of components that shape citizen's personal environmental citizenship, including "knowledge", "attitudes", "skills", "values", and "behaviors". Additionally, the EC competences cumulatively describe the ability of a citizen to act in a responsible way and actively participate in the civic and social arena based on a comprehensive understanding of the social, economic, scientific, cultural, and political concepts and structures, thus becoming an "agent of change".

\subsection{The EC Actions}

Citizens' potential actions within the context of environmental citizenship are situated at different dimensions (individual or collective), spheres (private or public), and scales (local, national, and global). More specifically, actions situated in the "individual" dimension, are those referring to personal actions, such as recycling and composting, whereas actions placed at the "collective" dimension are participatory actions, such as community actions to 
tackle pollution or the development of possible restoration actions of an ecosystem. Actions can also take place at various spheres, thus affecting the relations between individuals and societies (private) or the relations in societies (public). Finally, actions of environmental citizenship can be contextualized at various scales (local, national, global) according to their impact and scalability [17].

\subsection{The EEC Outcomes}

When citizens are equipped with the EC competences, they are then expected to undertake actions (of different dimensions, spheres, and scales) towards environmental citizenship to achieve specific environmental outcomes, which can promote environmental and social change. According to the EEC model, the main environmental outcomes are the following: (a) solution of current environmental problems, (b) prevention of the creation of new environmental problems, (c) addressing the structural causes of environmental problems, (d) development of a healthy relationship with nature, (e) practice of environmental rights and duties, (f) achievement of critical and active engagement and civic participation, (g) promotion of inter/intra-generational justice, and (h) achievement of sustainability.

\section{Rationale}

The participation of citizens in environmental CS initiatives is assumed to increase their knowledge on environmental issues and to reinforce their pro-environmental attitudes, which sequentially intensifies their pro-environmental behaviors towards environmental management and ecological conservation [22]. According to a recent study by Jørgensen and Jørgensen (2020), environmentally oriented CS may contribute to EEC, as it provides benefits beyond science and scientific knowledge gain [18]. Although several studies have documented how environmental competences foster pro-environmental behavior [23-25], to the best of our knowledge, there is lack of studies investigating how environmental CS initiatives may contribute to the development of EC competences, actions, and EEC outcomes. In this paper, we have conducted a systematic literature review to shed light on this issue, by exploring empirical research published during the last two decades (20002020). Overall, we sought to examine how participation in environmental CS initiatives may serve as a springboard to educate citizens to become environmental citizens, able to act as "agents of change".

\section{Research Questions (RQs)}

The main objective of our review study was to investigate whether participation in environmental CS initiatives could promote Education for Environmental Citizenship (EEC), as this was presented in Section 2. This objective was formulated in three research questions (RQs), as follows:

- RQ1: Whether participation in environmental CS initiatives contributes to the development of citizens' EC competences, actions, and EEC outcomes;

- RQ2: What are the main correlations among the EC competences, actions, and EEC outcomes in the reviewed environmental CS initiatives?

- RQ3: Which are the more salient components from the EC competences, actions, and EEC outcomes in the reviewed environmental CS initiatives?

\section{Methodology}

\subsection{Data Collection}

The studies analyzed in this literature review covered empirical research published in peer-reviewed academic journals, in the English language, during the timespan of the last twenty years, from 2000 to 2020 . The retrieval of the reviewed studies followed the PRISMA standards for systematic literature reviews (http:/ / prisma-statement.org/, accessed on 2 September 2020) and was based on a multi-step procedure comprised of three sequential stages, as follows: (a) Identification, (b) Screening, and (c) Eligibility (Figure 2). 

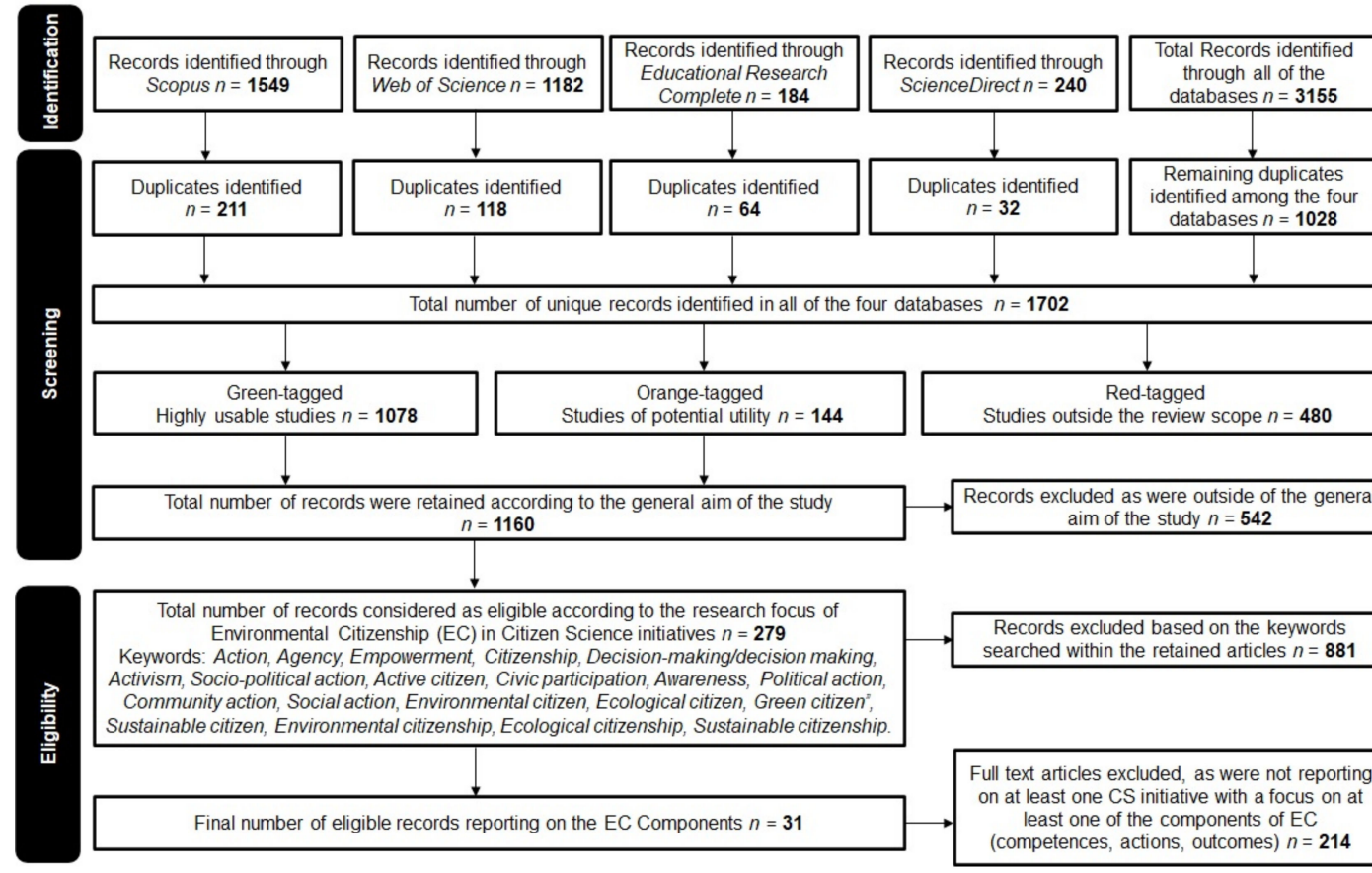

through all of the databases $n=3155$

Duplicates identified

$n=211$

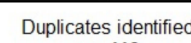

$n=118$

$n=64$

$n=32$

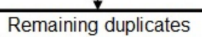

dentified among the four databases $n=1028$
ditified among the fol

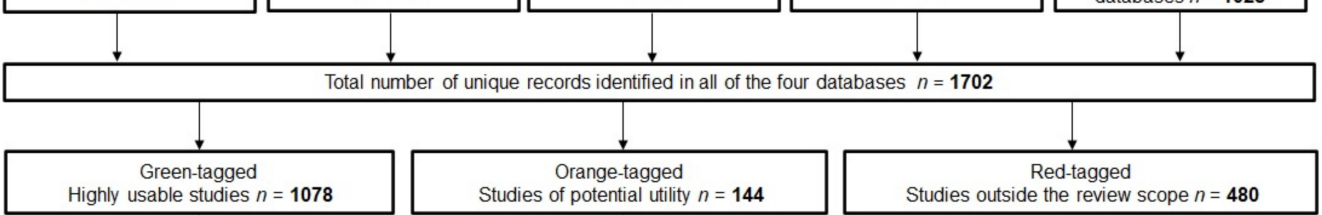

Highly usable studies $n=1078$ Studies of potential utility $n=144$

Studies outside the review scope $n=\mathbf{4 8 0}$

Total number of records were retained according to the general aim of the study

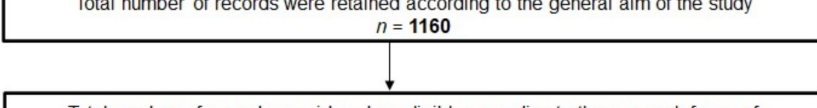

Total number of records considered as eligible according to the research focus Environmental Citizenship (EC) in Citizen Science initiatives $n=\mathbf{2 7 9}$

Keywords: Action, Agency, Empowerment, Citizenship, Decision-making/decision making Activism, Socio-political action, Active citizen, Civic participation, Awareness, Political action, Community action, Social action, Environmental citizen, Ecological citizen, Green citizen Sustainable citizen, Environmental citizenship, Ecological citizenship, Sustainable citizenship.

Final number of eligible records reporting on the EC Components $n=\mathbf{3 1}$

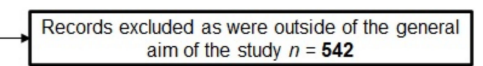

Records excluded based on the kewords searched within the retained articles $n=\mathbf{8 8}$

Full text articles excluded, as were not reporting on at least one CS initiative with a focus on least one of the components of $E C$

(competences, actions, outcomes) $n=214$

Figure 2. Flow diagram of the systematic literature review selection process.

The identification step included the survey of the published literature using four (4) electronic databases, as follows: Scopus, Web of Science, Education Research Complete (via EBSCO), and ScienceDirect. Within each database, the terms "Citizen science", "Open science", "Public science", "Participatory science", "Civic science", and "Community science", were combined with the terms "Environment", "Nature", and "Ecology", e.g., "Citizen Science" AND "Environment", "Open Science" and "Nature", thus leading to 18 combinations. The retrieved studies have been checked within the title, abstract and keywords, to ensure that they would be mostly restricted in the context of environmental CS initiatives. Therefore, a total number of 3155 studies were obtained as of September 2020.

The screening step over the latter studies included the removal of duplicates within and among the four databases, leading to a total of 1702 peer-reviewed studies. This step also included the color-tagging of the 1702 studies as green, orange, or red, according to their alignment with the research scope of this review study; namely, the study should report on the design, implementation, and/or management of at least one environmental CS initiative. More specifically, the green-tagging was used for highly usable studies, in contrast to the red-tagging which referred to studies outside the scope of this review. Studies of potential utility were marked with the orange-tagging, as it was not straightforwardly obvious whether they were aligned or not with the research scope of this study. In this case, the full text versions of these studies were examined to ensure that they were reporting on the design, implementation, and/or management of an environmental CS initiative. The screening step resulted in 1160 green-tagged publications.

As part of the eligibility step the 1160 retained publications were further evaluated according to their research focus on Environmental Citizenship (EC) and Education for Environmental Citizenship (EEC). In this case, an initial filtering was performed by examining the retained articles' title, abstract, and keywords for any mention of the following terms: "Action", "Agency", "Empowerment", "Citizenship", "Decision-making", "Activism", "Socio-political action", "Active citizen", "Civic participation", "Awareness", "Political action", "Community action", "Social action", "Environmental citizen”, "Ecological citizen", "Green citizen", "Sustainable citizen", "Environmental citizenship", "Ecological citizenship", and "Sustainable citizenship". 
This iterative search process resulted in 279 peer-reviewed journal articles that were categorized according to their research methods into: (i) empirical papers, reporting on the implementation of at least one environmental CS initiative, (ii) review papers, and (iii) theoretical papers, which were not providing any empirical data. This categorization led to 65 relevant empirical articles which were thoroughly examined according to two main inclusion criteria, as follows: (a) a study should evaluate and report on the impact of the environmental CS initiative on any of the EC competences, actions, or EEC outcomes at the article's results, discussion, and/or conclusions and, in order to do so, (b) a study should adopt various evaluations techniques (e.g., interviews, surveys and questionnaires, etc.). The implementation of this criteria ultimately resulted to 31 empirical studies, which composed our data corpus and were further analyzed for the purposes of this review study. All the reviewed studies are marked with an asterisk at the references.

\subsection{Data Analysis}

\subsubsection{Coding Scheme}

For the purposes of our study, we initially developed a comprehensive typology which served as the coding scheme for capturing the main EC components (competences, actions, and outcomes), as these were reported in the reviewed environmental CS initiatives. In order to do so, we adopted a multi-step process (see Figure 3).

\section{Step A EEC model \\ The Education for Environmental Citizenship model (EEC model), conceptualized by ENEC, was used as the basis for the
creation of our Typology \\ Step B \\ Deconstruction of the EEC model}

Deconstruction of the EEC model to its constitutional elements of: Competences

Actions

Environmental Outcomes

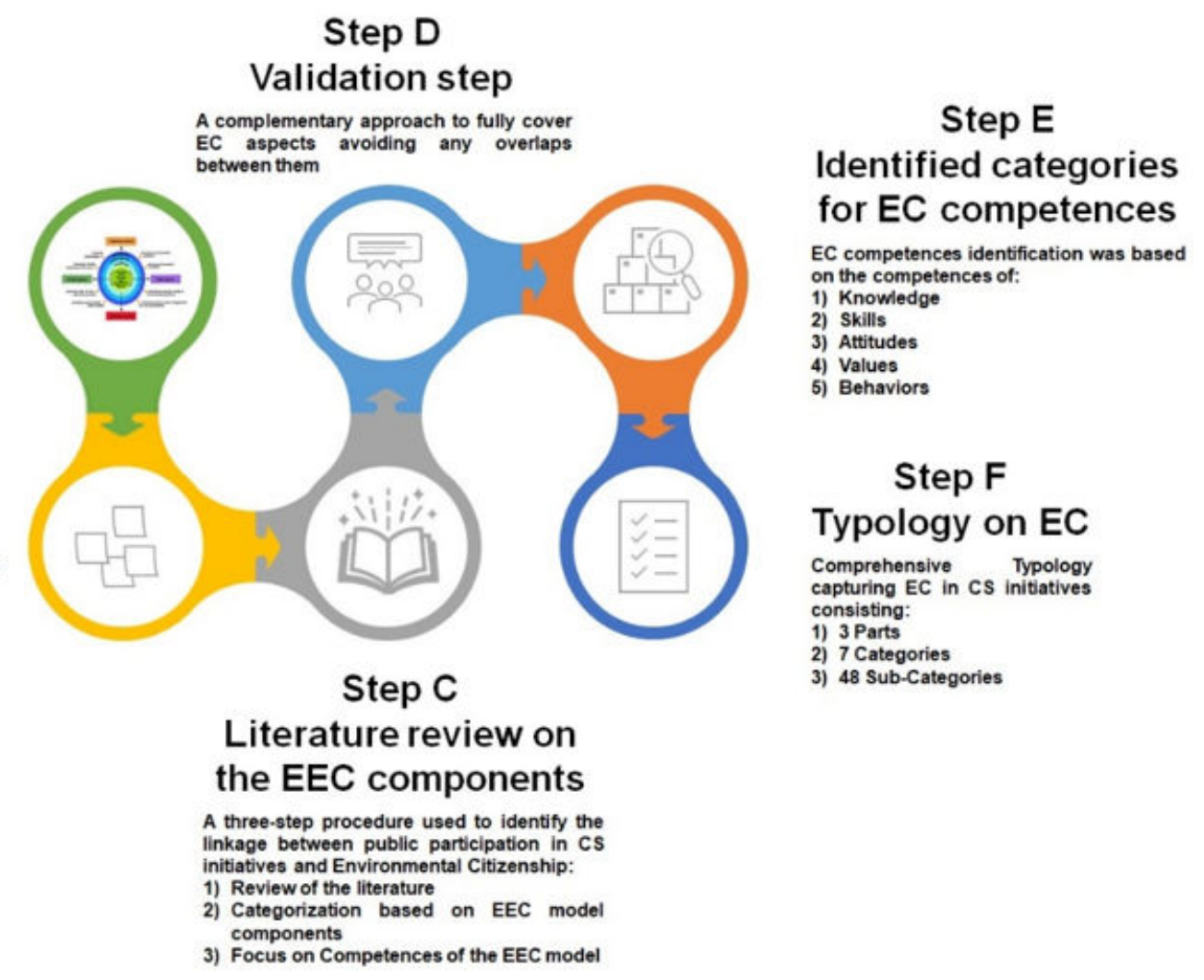

Figure 3. Steps followed for the development of the EEC typology.

More specifically, the EEC model was used as the basis on which our typology was developed (Figure 3, Step A). Further exploitation of the EEC model led to its analysis into its constitutional components of: (a) EC competences, (b) EC actions, and (c) EEC outcomes (Figure 3, Step B). The possible links between EEC and environmental CS initiatives were explored by: (a) reviewing the literature on the components of the EEC model, (b) forming categories that are more closely aligned with the principles of EC, and (c) deepening into the component of EEC competences (Figure 3, Step C). During the development of the typology, a complementary approach (validation step) was adopted, to fully cover all 
aspects of the EC competences in a non-overlapping way (Figure 3, Step D). In particular, special emphasis was given on the EC competences representing the competences of knowledge, attitudes, skills, values, and behaviors within the core of Environmental Citizenship expressions, as shown in Table 1 (Figure 3, Step E). Overall, this process led to a typology (Figure 3, Step F) consisting of 7 categories, which are further divided into 48 sub-categories (Table 1), along with their original source.

Table 1. Typology of Environmental Citizenship (EC).

\begin{tabular}{|c|c|}
\hline EC Components & Sources \\
\hline \multicolumn{2}{|l|}{ EC Competences: Knowledge (EC-C-K) } \\
\hline Environmental Systems Knowledge (ESK) & [26] \\
\hline Action-Related Knowledge (ARK) & [26] \\
\hline Self-Effectiveness Knowledge (SEK) & [26] \\
\hline Political Systems Knowledge (PSK) & [27] \\
\hline Transformative Action Knowledge (TAK) & [27] \\
\hline \multicolumn{2}{|l|}{ EC Competences: Skills (EC-C-S) } \\
\hline Collaboration and Social Interaction Skills (CSIS) & {$[17,28]$} \\
\hline Critical Thinking Skills (CTS) & {$[17,28]$} \\
\hline Problem-Solving Skills (PSS) & {$[17,28]$} \\
\hline Communication Skills (CS) & {$[17,28]$} \\
\hline Systems Thinking Skills (STS) & [17] \\
\hline Evidence-Based Thinking Skills (EBTS) & [17] \\
\hline Decision-Making Skills (DMS) & [17] \\
\hline Argumentation Skill (AS) & [28] \\
\hline Constructive Participation Skills (CPS) & [28] \\
\hline Interacting with Media Skills (IMS) & [28] \\
\hline Critical Understanding of Media Skills (CUMS) & [28] \\
\hline \multicolumn{2}{|l|}{ EC Competences: Attitudes (EC-C-A) } \\
\hline Willingness to Act in Society as Agents of Change (WASAC) & [17] \\
\hline Willingness to Eliminate New Environmental Problems (WENEP) & [17] \\
\hline Willingness for Collective Environmental Actions (WCEA) & [17] \\
\hline Willingness for Networking to Solve Environmental Problems (WNSEP) & [17] \\
\hline Respect for Environmental Rights (RER) & [28] \\
\hline Willingness for Democratic Decision-Making (WDDM) & [28] \\
\hline Willingness for Intercultural Communication for the Environment (WICE) & [28] \\
\hline Willingness to Take Responsibility for the Environment (WTRE) & [28] \\
\hline Willingness for Environmental and Social Justice (WESJ) & [28] \\
\hline \multicolumn{2}{|l|}{ EC Competences: Values (EC-C-V) } \\
\hline Biospheric Values (BV) & [29] \\
\hline EC Components & Sources \\
\hline Altruistic Values (AV) & [29] \\
\hline Egoistic Values (EV) & [29] \\
\hline Hedonic Values (HV) & [29] \\
\hline
\end{tabular}


Table 1. Cont.

\begin{tabular}{ll}
\hline EC Competences: Behaviors (EC-C-B) & {$[30]$} \\
\hline Activism Behaviors (AB) & {$[30]$} \\
\hline Non-Activist Behaviors (NAB) & {$[30]$} \\
\hline Private Sphere Behaviors (PSB) & {$[30]$} \\
\hline Other Behaviors (OB) & {$[17]$} \\
\hline EC Actions (EC-A) & {$[17]$} \\
\hline Collective Actions (CA) & {$[17]$} \\
\hline Individual Actions (IA) & {$[17]$} \\
\hline Private Sphere Actions (PrSA) & {$[17]$} \\
\hline Public Sphere Actions (PuSA) & {$[17]$} \\
\hline Local Scale Actions (LSA) & {$[17]$} \\
\hline National Scale Actions (NSA) & {$[17]$} \\
\hline Global Scale Actions (GSA) & {$[17]$} \\
\hline EEC Outcomes (EEC-O) & {$[17]$} \\
\hline Development of Healthy Relationship with Nature (HRN) & {$[17]$} \\
\hline Prevention of New Environmental Problems (PNEP) & {$[17]$} \\
\hline Solution of Environmental Problems (SEP) & {$[17]$} \\
\hline Achievement of Sustainability (AS) & {$[17]$} \\
\hline Achievement of Critical and Active Engagement and Civic Participation (CAE) \\
\hline Promotion of Inter/Intra-Generational Justice (IGJ) & \\
\hline Practice of Environmental Rights and Duties (ERD) & \\
\hline Addressing Structural Causes of Environmental Problems (SCEP) & \\
\hline
\end{tabular}

\subsubsection{Content Analysis}

The three (3) EC components (EC competences, EC actions, EEC outcomes) in the reviewed environmental CS initiatives $(n=31)$ were examined with qualitative content analysis coding; namely, each one of the environmental CS initiatives comprised the unit of our analysis. In each one of the reviewed CS initiatives, we were coding the presence/impact (1) or the absence/no impact (0) of the CS initiative on the EC competences, actions, and EEC outcomes according to our coding scheme (see Section 2.1). An indicative excerpt for each one of the coding sub-categories is presented in Supplementary Materials, Table S1. The reviewed articles on content analysis are presented in Supplementary Materials, S2.

\section{Inter-Reliability Process}

To ensure that all the coded data had been interpreted correctly, a validation process of three stages was implemented. In the first stage, the third co-author was assigned to peer review the work of the initial coding, by thoroughly reading each coded article, reviewing the metadata in each sub-category, and proposing amendments that better capture the content of the EC. Inter-coder reliability for the coded variables was approximately $85 \%$. The second validation stage was applied in cases where no mutual consensus on coding was observed between the first two co-authors. In this case, the fourth co-author was assigned to peer review the related sub-categories and make suggestions for the final decision. It is noteworthy mentioning that the final coding of the response variables was validated only in the case of mutual consent among the three co-authors. The final stage of the validation process was performed to increase the coding validity, where a fourth peer-review process was elaborated by all co-authors for the complete examination and finalization of the coding scheme. 


\subsubsection{Descriptive Analysis}

Initially, to investigate our first research question (environmental CS initiatives' contribution to the development of citizens scientists' EC competences, actions, and outcomes) we deployed a descriptive analysis to identify the extent to which the constitutional elements of EC (competences, actions, outcomes), were promoted in the reviewed environmental CS initiatives. More specifically, we coded and calculated the frequency of the EC components according to the EC typology, as well as the percentage they covered in the reviewed environmental CS initiatives. For instance, the EC sub-category of Environmental Systems Knowledge (ESK) was found in 19 of the 31 reviewed environmental CS initiatives; therefore, ESK was reported in $61.3 \%$ of the reviewed environmental CS initiatives.

\subsubsection{Bivariate Correlations}

To investigate our second research question (main correlations between the EC competences, actions, and outcomes in the reviewed environmental CS initiatives) we deployed a bivariate correlations analysis using the Statistical Package for the Social Sciences (SPSS V.24.0). More specifically, all computations were performed to identify the possible linkages between EC competences, actions, and outcomes as promoted in the context of the reviewed environmental CS initiatives, using the Spearman's Rank-Order correlation analysis. Spearman's rank correlation was selected as a non-parametric statistical analysis to examine the strength of association between two variables. The significance level was set at $p<0.05$ to define the minimum acceptable level of significance, while the strength of correlation was based on the range of the $r$ coefficient, with $0.00-0.19$ indicating a very weak correlation, $0.20-0.39$ a weak correlation, $0.40-0.59$ a moderate correlation, $0.60-0.79$ a strong correlation, and $0.80-1.0$ a very strong correlation [31].

\subsubsection{K-Means Cluster Analysis}

To investigate our third research question (the most salient components from the EC competences, actions, and outcomes in the reviewed environmental CS initiatives) we focused on the connections between the EC components, as these emerged in the context of the bivariate correlations (see Section 5.2.4). At a first step we calculated the number of connections (moderate and strong correlations) of each EC component with the rest of the other components, and we then created a frequency table indicating how many connections were identified for each of the 48 EC components. At a second step we deployed a K-means cluster analysis to classify the components in two homogenous groups, taking into account the number of their connections with the rest of the EC components [32]. Put simply, Kmeans cluster analysis uses Euclidean distance to classify data in a number of pre-defined groups through multiple iterations; this process continues until cluster means do not shift more than a given cut-off value or the iteration limit is reached. In this way, we aimed at setting a cut-off point to classify the EC components into: (a) "Keystone Components" (KCs), namely components with the greatest number of connections, and (b) "Peripheral Components" (PCs), namely components with a lower number of connections with the rest of the ECC components.

\section{Results}

What follows is the presentation of the findings derived from the data analysis. The findings are presented according to the research questions guiding this study.

\subsection{RQ1: Whether Participation in Environmental CS Initiatives Contributes to the Development} of Citizens' EC Competences, Actions and Outcomes

To address RQ1, as already mentioned, a qualitative content analysis was conducted as an inductive approach to capture the EC competences, actions, and outcomes, which were promoted due to the participation of citizens in environmental CS initiatives. In the following sub-sections, we present the main findings derived regarding the three EC components: (a) competences, (b) actions, and (c) outcomes. 


\subsubsection{Overview of EC Competences}

Our results revealed that environmental CS initiatives provided a fertile context for the EC to take place which, in turn, had a positive impact on the participating citizens competences. Overall, as presented in Table 2, the reviewed environmental CS initiatives mainly contributed to the enhancement of the citizens' Knowledge $(n=25$ CS initiatives, $80.5 \%$ ), and Skills ( $n=27$ CS initiatives, $87.1 \%$ ), and to a lesser degree to the enhancement of Attitudes ( $n=19$ CS initiatives, $61.3 \%$ ), Values ( $n=11$ CS initiatives, $35.5 \%)$, and Behaviors $(n=8$ CS initiatives, $25.8 \%)$.

Table 2. Absolute number and percentage of CS initiatives reporting on the development of the EC competences.

\begin{tabular}{|c|c|c|}
\hline EC Competences & $\mathbf{N}$ & $\%$ \\
\hline Knowledge (EC-C-K) & $n=25$ & $80.5 \%$ \\
\hline Environmental Systems Knowledge (ESK) & $n=19$ & $61.3 \%$ \\
\hline Action-Related Knowledge (ARK) & $n=11$ & $35.5 \%$ \\
\hline Self-Effectiveness Knowledge (SEK) & $n=11$ & $35.5 \%$ \\
\hline Political Systems Knowledge (PSK) & $n=2$ & $6.5 \%$ \\
\hline Transformative Action Knowledge (TAK) & $n=1$ & $3.2 \%$ \\
\hline Skills (EC-C-S) & $n=27$ & $87.1 \%$ \\
\hline Collaboration and Social Interaction Skills (CSIS) & $n=16$ & $51.6 \%$ \\
\hline Evidence-Based Thinking Skills (EBTS) & $n=16$ & $51.6 \%$ \\
\hline Interacting with Media Skills (IMS) & $n=13$ & $41.9 \%$ \\
\hline Critical Understanding of Media Skills (CUMS) & $n=7$ & $22.6 \%$ \\
\hline Critical Thinking Skills (CTS) & $n=7$ & $22.6 \%$ \\
\hline Problem-Solving Skills (PSS) & $n=7$ & $22.6 \%$ \\
\hline Communication Skills (CS) & $n=6$ & $19.4 \%$ \\
\hline Constructive Participation Skills (CPS) & $n=5$ & $16.1 \%$ \\
\hline Systems Thinking Skills (STS) & $n=4$ & $12.9 \%$ \\
\hline Decision-Making Skills (DMS) & $n=1$ & $3.2 \%$ \\
\hline Argumentation Skill (AS) & $n=1$ & $3.2 \%$ \\
\hline Attitudes (EC-C-A) & $n=19$ & $61.3 \%$ \\
\hline Willingness for Collective Environmental Actions (WCEA) & $n=14$ & $45.2 \%$ \\
\hline Willingness to Act in Society as Agents of Change (WASAC) & $n=10$ & $32.3 \%$ \\
\hline Willingness to Eliminate New Environmental Problems (WENEP) & $n=8$ & $25.8 \%$ \\
\hline $\begin{array}{l}\text { Willingness for Networking to Solve Environmental Problems } \\
\text { (WNSEP) }\end{array}$ & $n=4$ & $12.9 \%$ \\
\hline Willingness for Democratic Decision-Making (WDDM) & $n=2$ & $6.5 \%$ \\
\hline $\begin{array}{l}\text { Willingness for Intercultural Communication for the Environment } \\
\text { (WICE) }\end{array}$ & $n=1$ & $3.2 \%$ \\
\hline Willingness for Environmental and Social Justice (WESJ) & $n=1$ & $3.2 \%$ \\
\hline Willingness to Take Responsibility for the Environment (WTRE) & $n=0$ & $0 \%$ \\
\hline Respect for Environmental Rights (RER) & $n=0$ & $0 \%$ \\
\hline Values (EC-C-V) & $n=11$ & $35.5 \%$ \\
\hline Biospheric Values (BV) & $n=16$ & $51.6 \%$ \\
\hline
\end{tabular}


Table 2. Cont.

\begin{tabular}{lcc}
\hline EC Competences & $\mathbf{N}$ & $\mathbf{\%}$ \\
\hline Egoistic Values (EV) & $n=5$ & $16.1 \%$ \\
\hline Hedonic Values (HV) & $n=5$ & $16.1 \%$ \\
\hline Altruistic Values (AV) & $n=3$ & $9.7 \%$ \\
\hline Behaviors (EC-C-B) & $\boldsymbol{n}=\mathbf{8}$ & $\mathbf{2 5 . 8 \%}$ \\
\hline Private Sphere Behaviors (PSB) & $n=6$ & $19.4 \%$ \\
\hline Activism Behaviors (AB) & $n=2$ & $6.5 \%$ \\
\hline Non-Activist Behaviors (NAB) & $n=1$ & $3.2 \%$ \\
\hline Other Behaviors (OB) & $n=1$ & $3.2 \%$ \\
\hline
\end{tabular}

More specifically, according to our findings a main goal of environmental CS initiatives was to equip citizens with the necessary skills and knowledge to be able to collect reliable datasets, thus giving less attention in fostering the pro-environmental values, attitudes, or behaviors of the participating citizens. Put simply, given that the environmental CS initiatives' focus is usually placed on data collection and environmental monitoring processes, in their majority, the reviewed environmental CS initiatives were designed to engage citizens in scientific research, thus promoting the development of substantial skills and knowledge.

\section{EC Competences: Knowledge}

As presented in Table 2, we have found that the reviewed environmental CS projects promoted various types of knowledge. More specifically, our findings revealed that the majority of the reviewed CS initiatives reported on the enhancement of Environmental Systems Knowledge (ESK) $(n=19$ CS initiatives, $61.3 \%)$, followed by Self-Effectiveness Knowledge (SEK) ( $n=11$ CS initiatives, 35.5\%), and Action-Related Knowledge (ARK) ( $n=11$ CS initiatives, $35.5 \%$ ). These results show the potential that such initiatives have to enhance citizens' knowledge on how the natural states of ecosystems operate and the interrelated processes within them, the benefit (effectiveness) of environmentally responsible actions, as well as on what actions can be taken in order to address an environmental problem. On the other hand, Political Systems Knowledge (PSK) $(n=2$ CS initiatives, $6.5 \%)$, and Transformative Action Knowledge (TAK) ( $n=1$ CS initiative, $3.2 \%$ ) were found to be among the less prevalent types of knowledge that are promoted in environmental CS projects.

\section{EC Competences: Skills}

As shown in Table 2, the more promoted EC skills referred to Collaboration and Social Interaction Skills (CSIS), namely to the ability of individuals to effectively engage with and co-work with others in common or public interest, in relation to environmental issues ( $n=16$ CS initiatives, $51.6 \%$ ); to Evidence-Based Thinking Skills (EBTS) ( $n=16$ CS initiatives, $51.6 \%)$; as well as to interacting with media skills (IMS) $(n=13$ CS initiatives, $41.9 \%$ ). On the other hand, our findings indicated that the reviewed environmental CS initiatives gave less attention to the development of citizens' Problem-Solving Skills (PSS) ( $n=7$ CS initiatives, 22.6\%); Critical Understanding of Media Skills (CUMS) in the frame of preventing and solving environmental problems ( $n=7$ CS initiatives, 22.6\%); Critical Thinking Skills ( $n=7$ CS initiatives, 22.6\%); Communication Skills (CS) ( $n=6$ CS initiatives, $19.4 \%$ ); Constructive Participation Skills (CPS) in community activities ( $n=5$ CS initiatives, $16.1 \%)$; Systems Thinking Skills (STS) ( $n=4$ CS initiatives, $12.9 \%$ ); Decision-Making Skills (DMS) ( $n=1$ CS initiative, 3.2\%); and Argumentation Skills (AS) ( $n=1$ CS initiative, 3.2\%). 


\section{EC Competences: Attitudes}

Considering the development of the EC attitudes, as shown in Table 2, most of the reviewed environmental CS initiatives had an impact on the Willingness for Collective Environmental Actions (WCEA) in addition to individual actions for the protection of the environment ( $n=14$ CS initiatives, $45.2 \%$ ), Willingness to Act in Society as Agent of Change (WASAC) ( $n=10$ CS initiatives, 32.3\%), Willingness to Eliminate New Environmental Problems (WENEP) ( $n=8$ CS initiatives, 25.8\%) or willingness for networking to solve environmental problems (WNSEP) at the local, national and global scale $(n=4$ CS initiatives, $12.9 \%$ ). These results show that environmental CS initiatives have the potential to promote or reinforce pro-environmental attitudes through strengthening the interrelationships among the social networks, and thus contributing to attitudinal and behavioral change of individuals. Attitudes, such as Willingness for Democratic Decision-Making (WDDM) ( $n=2$ CS initiatives, $6.5 \%$ ), Willingness for Intercultural Communication for the Environment (WICE) ( $n=1$ CS initiative, 3.2\%), as well as Willingness for Environmental and Social Justice (WESJ) ( $n=1$ CS initiative, 3.2\%), were also found to be cultivated in participants, though in a very limited degree. Finally, our content analysis showed that the EC attitudes of Respect for Environmental Rights (RER) and Willingness to Take Responsibility for the Environment (WTRE) were not promoted at all in the reviewed CS initiatives.

\section{EC Competences: Values}

According to our results, as far as it concerns the EC values (see Table 2), we found that participation in environmental CS initiatives mostly contributed to the development of Biospheric Values (BV) ( $n=16$ CS initiatives, 51.6\%). We also identified an equal distribution of CS initiatives reporting on Hedonic Values (HV) and Egoistic Values (EV) ( $n=5$ CS initiatives each, 16.1\%). Finally, Altruistic Values (AV) were only promoted in a limited number of CS initiatives ( $n=3$ CS initiatives, 9.7\%). Overall, our findings revealed that participation in environmental CS initiatives strongly promotes Biospheric Values (BV), which underly environmental preservation and restoration actions, and favors behavioral changes in the general public.

\section{EC Competences: Behaviors}

In line with the previous results, under the EC Behaviors, we have identified that participation in environmental CS initiatives seems to have a positive impact on the behavioral profile of individuals. More specifically, as shown in Table 2, some of the reviewed CS initiatives reported a positive effect regarding the Private Sphere Behaviors (PSB) $(n=6$ CS initiatives, $19.4 \%$ ), while a lower number of CS initiatives also reported on the promotion of Activism Behaviors (AB) ( $n=2$ CS initiatives, $6.5 \%)$, Non-Activist Behaviors (NAB) $(n=1$ CS initiative, $3.2 \%$ ), and Other Behaviors $(\mathrm{OB})$, namely behaviors indicating an indirect influence of individuals to their organizations ( $n=1$ CS initiative, $3.2 \%$ ).

\subsubsection{EC Actions}

Our review highlights that the participation in environmental CS initiatives has a positive impact that extends beyond citizens' competences. More specifically, we have found that participation in environmental CS initiatives empowers citizens' EC actions, according to the three axes of the EEC model: (a) Dimensions: Individual/Collective actions; (b) Spheres: Private/Public actions; (c) Scales: Local/National/Global actions (Figure 4). 


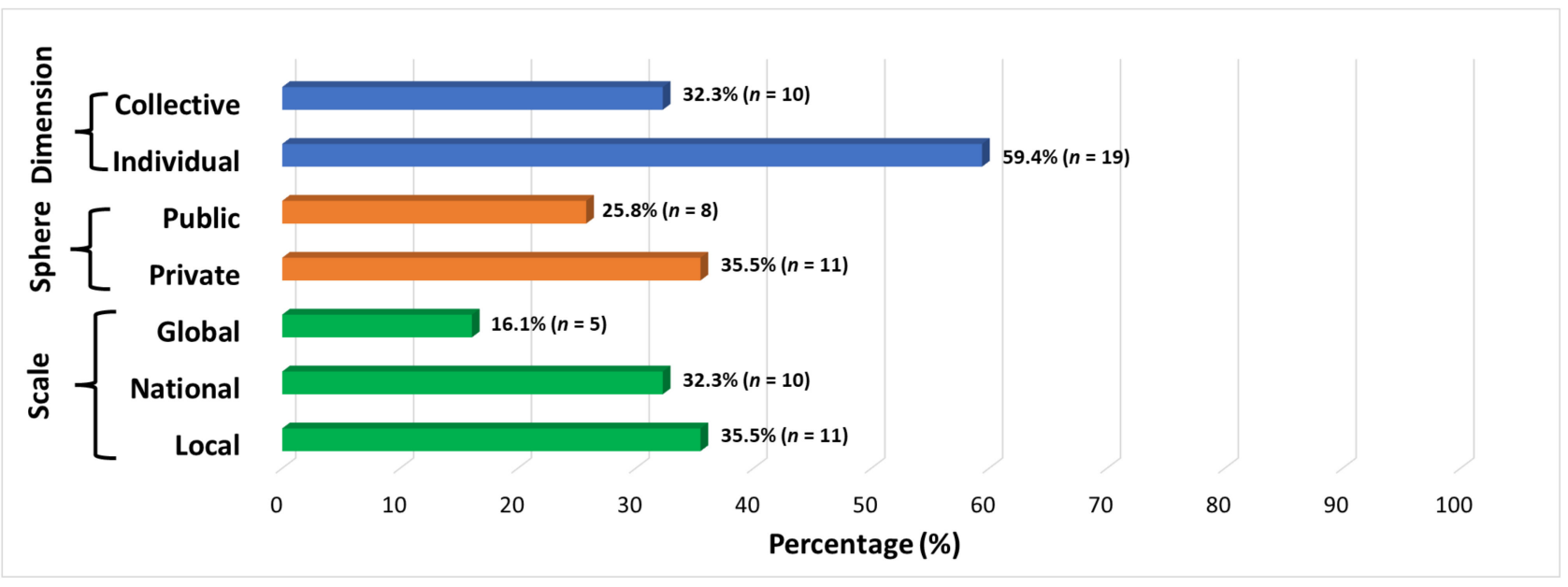

Figure 4. Absolute number and percentage of environmental CS Initiatives reporting on the promotion of EC actions per dimension, sphere, and scale.

More precisely, we have found that the majority of the reviewed environmental CS initiatives were related with the empowerment of citizen's Individual Actions (IA) $(n=19$ CS initiatives, 59.4\%) rather than Collective Actions (CA) ( $\mathrm{n}=10$ CS initiatives, $32.3 \%)$, as well as with the empowerment of Private Sphere Actions (PrSA) $(n=11$ CS initiatives, 35.5\%) rather than the Public Sphere Actions (PuSA) ( $n=8$ CS initiatives, 25.8\%). We have also found that most of the environmental CS initiatives were related to the empowerment of citizen's Local Scale Actions (LSA) ( $n=11$ CS initiatives, 35.5\%) and National Scale Actions (NSA) ( $n=10$ CS initiatives, 32.3\%), rather than to the Global Scale Actions (GSA) ( $n=5$ CS initiatives, $16.1 \%$ ).

\subsubsection{EEC Outcomes}

An overview of the EEC outcomes, as identified in the reviewed environmental CS initiatives, is presented in Table 3.

Table 3. Absolute number and percentage of environmental CS initiatives reporting on the achievement of EEC Outcomes.

\begin{tabular}{lcc}
\hline EEC Outcomes & $\mathbf{N}$ & $\%$ \\
\hline Development of Healthy Relationship with Nature (HRN) & $n=15$ & $48.4 \%$ \\
\hline Prevention of New Environmental Problems (PNEP) & $n=14$ & $45.2 \%$ \\
\hline Solution of Environmental Problems (SEP) & $n=13$ & $41.9 \%$ \\
\hline Achievement of Sustainability (AS) & $n=6$ & $19.4 \%$ \\
\hline $\begin{array}{l}\text { Achievement of Critical and Active Engagement and Civic } \\
\text { Participation (CAE) }\end{array}$ & $n=1$ & $3.2 \%$ \\
\hline Promote Inter/Intra-Generational Justice (IGJ) & $n=1$ & $3.2 \%$ \\
\hline Practice Environmental Rights and Duties (ERD) & $n=0$ & $0 \%$ \\
\hline Address Structural Causes of Environmental Problems (SCEP) & $n=0$ & $0 \%$ \\
\hline
\end{tabular}

Based on our findings, the most frequently reported EEC outcome (see Table 3) was the Development of Healthy Relationship with Nature (HRN) ( $n=15$ CS initiatives, 48.4\%); this one, most of the time, was discussed as a need to connect with nature. The second most reported EEC outcome was the Prevention of New Environmental Problems (PNEP) ( $n=14$ CS initiatives, $45.2 \%$ ), while the third one was the Solution of Environmental Problems (SEP) ( $n=13$ CS initiatives, $41.9 \%$ ). More specifically, a variety of environmental CS initiatives seemed to contribute to the ecosystem stewardship by employing appropriate strategies 
for better-informed management and control techniques. A lesser emphasis was captured on the promotion of outcomes, such as the Achievement of Sustainability (AS) ( $n=6$ CS initiatives, $19.4 \%$ ), and only a very small proportion of the reviewed CS initiatives, was found to result in outcomes such as the Achievement of Critical and Active Engagement and Civic Participation (CAE) ( $n=1$ CS initiative, $3.2 \%)$ as well as the Promotion of Inter/Intra-Generational Justice (IGJ) ( $n=1$ CS initiative, 3.2\%).

6.2. RQ2: What Are the Main Correlations, among the EC Competences, Actions, and EEC Outcomes in the Reviewed Environmental CS Initiatives?

According to our second research question we aimed at exploring and further understanding if and how: (a) the EC competences are inter-related, (b) the EC competences are correlated to EC actions and EEC outcomes, and (c) the EC actions are correlated to the EEC outcomes. In the next sub-sections, we present our findings according to the aforementioned bivariate correlations.

\subsubsection{Correlations between the EC Competences}

At our first step we aimed to identify and report all possible strong and moderate correlations among the EC competences: knowledge, skills, attitudes, values, and behaviors. An overview of these correlations is presented in Figure 5 and is further discussed in the following sub-sections.
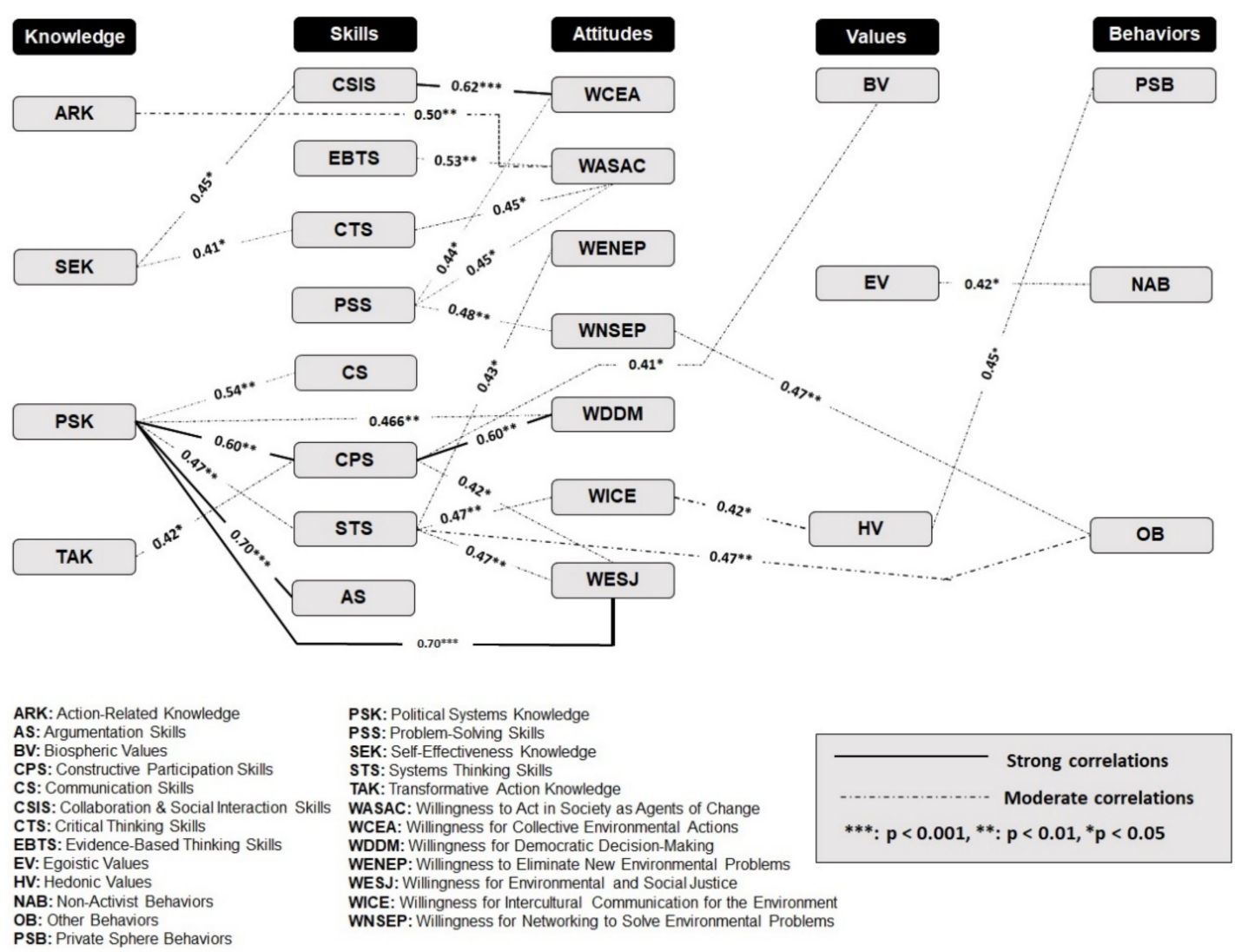

Figure 5. Correlations between the EC competences (knowledge, skills, attitudes, values, behaviors).

Correlations between EC Knowledge and Skills

Statistical analysis led to several moderate and strong positive correlations between EC knowledge and skills. In more details, strong positive correlations were observed between Political Systems Knowledge (PSK) with Argumentation Skills (AS) ( $r=0.70$, $p<0.001)$ and Constructive Participation Skills (CPS) $(\mathrm{r}=0.60, p<0.001)$. In addition, moderate positive correlations were observed between Political Systems Knowledge (PSK) 
with Communication Skills (C) $(r=0.54, p<0.01)$ as well as with Systems Thinking Skills (STS) $(r=0.47, p<0.01)$. In addition, moderate positive correlations were also identified between Transformative Action Knowledge (TAK) and Constructive Participation Skills (CPS) $(r=0.42, p<0.05)$, as well as between Self-Effectiveness Knowledge (SEK) with Collaboration and Social Interaction Skills (CSIS) $(r=0.45, p<0.05)$, and Self-Effectiveness Knowledge (SEK) with Critical Thinking Skills (CTS) $(\mathrm{r}=0.41, p<0.05)$.

Correlations between EC Knowledge and Attitudes

The examined correlations between EC knowledge and attitudes showed a strong positive correlation between Political Systems Knowledge (PSK) with Willingness for Environmental and Social Justice (WESJ) $(r=0.70, p<0.001)$. In addition, a moderate positive correlation was found between Action-Related Knowledge (ARK) and Willingness to Act in Society as Agents of Change (WASAC) $(r=0.50, p<0.01)$, as well as between Political Systems Knowledge (PSK) and Willingness for Democratic Decision-Making (WDDM) $(\mathrm{r}=0.47, p<0.01)$.

Correlations between EC Skills and Attitudes

The examined relations between EC skills and attitudes revealed a strong positive correlation between Collaboration and Social Interaction Skills (CSIS) and the Willingness for Collective Environmental Actions (WCEA) ( $\mathrm{r}=0.62, p<0.001)$, as well as between Constructive Participation Skills (CPS) and Willingness for Democratic Decision-Making (WDDM) $(r=0.60, p<0.001)$. In addition, we found a moderate positive correlation between Problem-Solving Skills (PSS) with: (a) Willingness for Networking to Solve Environmental Problems (WNSEP) $(\mathrm{r}=0.48, p<0.01)$, (b) Willingness to Act in Society as Agents of Change (WASAC) $(\mathrm{r}=0.45, p<0.05)$, and (c) Willingness for Collective Environmental Actions (WCEA) $(\mathrm{r}=0.44, p<0.05)$. Furthermore, we observed a moderate positive correlation between Systems Thinking Skills (STS) and Willingness for Intercultural Communication for the Environment (WICE) $(\mathrm{r}=0.47, p<0.01)$, Willingness for Environmental and Social Justice (WESJ) $(r=0.47, p<0.01)$ and Willingness to Eliminate New Environmental Problems (WENEP) $(\mathrm{r}=0.43, p<0.05)$, as well as between Evidence-Based Thinking Skills (EBTS) and Willingness to Act in Society as Agents of Change (WAS) $(r=0.53, p<0.01)$. Finally, Critical Thinking Skills (CTS) were found to be positively and moderately related to the Willingness to Act in Society as Agents of Change (WASAC) $(\mathrm{r}=0.45, p<0.05)$, and lastly, Constructive Participation Skills (CPS) with Willingness for Environmental and Social Justice (WESJ) $(\mathrm{r}=0.42, p<0.05)$.

Correlations between EC Skills and Values

According to the retrieved results on Spearman's correlations, we have identified only one correlation between EC skills and values. In particular, we have found a moderate positive correlation between Constructive Participation Skills (CPS) and Biospheric Values (BV) $(\mathrm{r}=0.41, p<0.05)$.

Correlations between EC Values and Attitudes

According to the retrieved results on Spearman's correlations, we have identified only one correlation between EC values and attitudes. In particular, we have found a moderate positive correlation between Hedonic Values (HV) and Willingness for Intercultural Communication for the Environment (WICE) $(r=0.42, p<0.05)$.

Interrelations between EC Values and Behaviors

Two moderate positive correlations were identified between EC values and behaviors. More specifically, we have found a positive moderate correlation between Hedonic Values $(\mathrm{HV})$ and Private Sphere Behaviors (PSB) $(\mathrm{r}=0.45, p<0.05)$, as well as between Egoistic Values (EV) and Non-Activist Behaviors (NAB) $(r=0.42, p<0.05)$. 
Correlations between EC Attitudes and Behaviors

According to the retrieved results on Spearman's correlations, we have identified only one correlation between EC attitudes and behaviors. More specifically, a moderate positive correlation was found to link Willingness for Networking to Solve Environmental Problems (WNSEP) and Other Behaviors (OB), indicating the indirect influence of individuals to their organizations and its consequent effects on the environment $(\mathrm{r}=0.47, p<0.01)$.

Correlations between EC Skills and Behaviors

According to the retrieved results on Spearman's correlations, we have identified only one correlation between EC skills and behaviors. In particular, Systems Thinking Skills (STS) were captured to be linked with a moderate positive correlation with Other Behaviors $(\mathrm{OB})$, indicating the indirect influence of individuals to their organizations and its consequent effects on the environment $(r=0.47, p<0.01)$.

\subsubsection{Correlations between the EC Competences and Actions}

At our second step we aimed to reveal all possible strong and moderate correlations among the EC competences and the EC actions. An overview of these correlations is presented in Figure 6 and is further discussed in the following sub-sections.

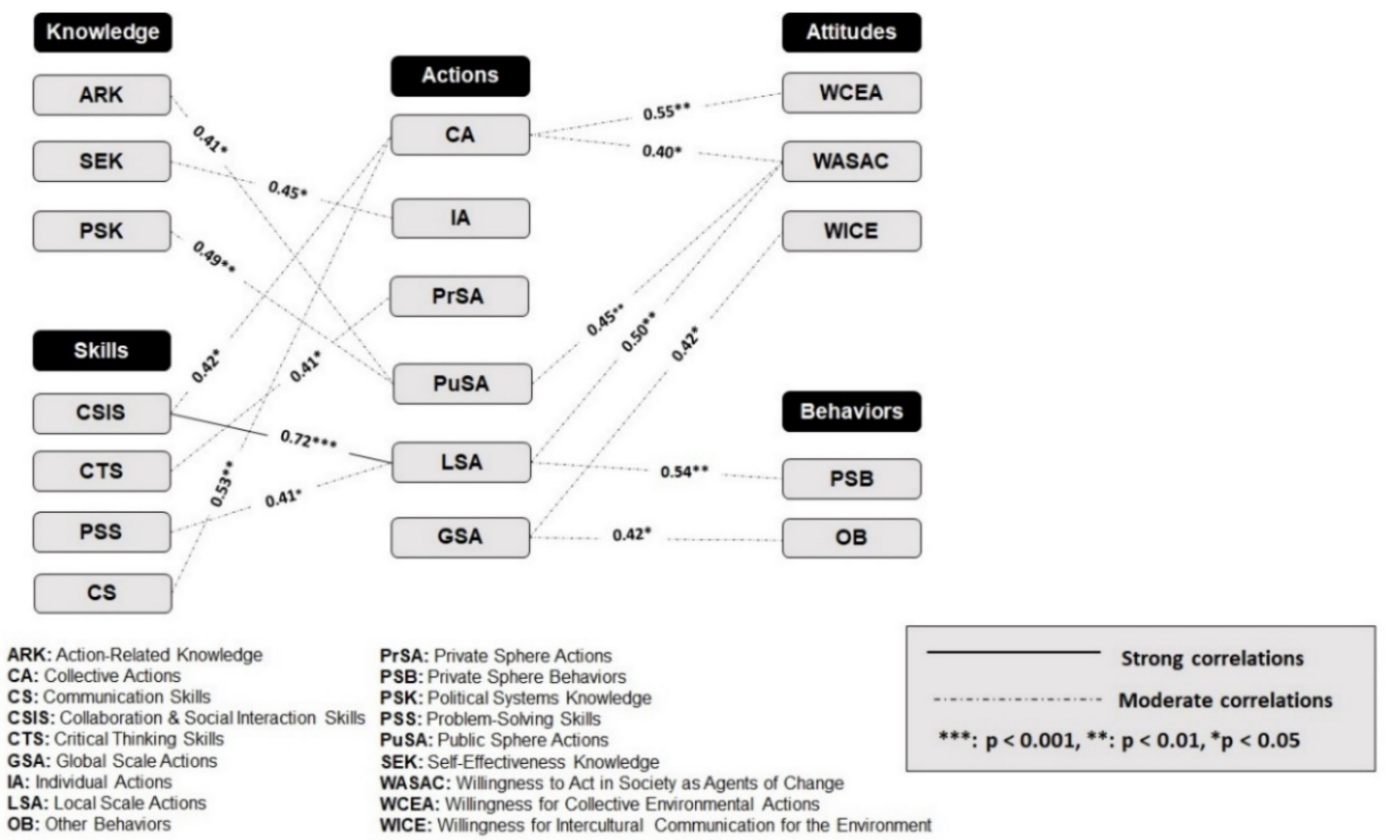

Figure 6. Correlations between the EC competences and actions.

Correlations between EC Knowledge and Actions

Several statistically significant correlations were found between EC knowledge and actions. In particular, Self-Effectiveness Knowledge (SEK) was positively related to Individual Actions (IA) $(\mathrm{r}=0.45, p<0.05)$. Political Systems Knowledge (PSK) as well as Action-Related Knowledge (ARK) were found to be positively related to Public Sphere Actions (PuSA) ( $\mathrm{r}=0.49, p<0.01$, and $\mathrm{r}=0.41, p<0.05$, respectively). Thus, participation in CS initiatives can help citizens use the knowledge gained from their experiences and apply it to local environmental issues the society is dealing with.

\section{Correlations between EC Skills and Actions}

Statistical analysis led to several moderate and strong positive correlations between EC skills and actions. More specific, Collaboration and Social Interaction Skills (CSIS) were found to be strongly related to Local Scale Actions (LSA) $(r=0.72, p<0.001)$ and moderately 
related to Collective Actions (CA) $(r=0.42, p<0.05)$. In addition, Critical Thinking Skills (CTS) were identified to be associated with Private Sphere Actions (PrSA) $(r=0.41$, $p<0.05)$, while Problem-Solving Skills (PSS) with Local Scale Actions (LSA) $(\mathrm{r}=0.41$, $p<0.05$ ). Communication Skills (CS) were found to be positively related to Collective Actions (CA) $(r=0.53, p<0.01)$, as well as to Local Scale Actions (LSA) $(r=0.49, p<0.01)$. This could be attributed to the fact that the majority of the retrieved studies reported on CS initiatives which were place-based focused, thus targeting local environmental problems.

Correlations between EC Attitudes and Actions

The examined relations between EC attitudes and actions revealed that Willingness for Collective Environmental Actions (WCEA) was found to be moderately associated to Local Scale Actions (LSA) $(r=0.55, p<0.01)$. In addition, Willingness to Act in Society as Agents of Change (WASAC0 was found to be positively correlated to Public Sphere Actions (PuSA) $(\mathrm{r}=0.45, p<0.01)$, Collective Actions (CA) $(\mathrm{r}=0.40, p<0.05)$ and Local Scale Actions (LSA) $(r=0.50, p<0.01)$. Finally, a moderate correlation was also observed between Willingness for Intercultural Communication for the Environment (WICE) and Global Scale Actions (GSA) $(r=0.42, p<0.05)$.

Correlations between EC Values and Actions

According to the retrieved results on Spearman's correlations, we have identified only one correlation between EC values and actions. More specifically, Hedonic Values (HV) were found to be linked with moderate positive correlation with National Scale Actions (NSA) $(r=0.45, p<0.05)$.

Correlations between EC Behaviors and Actions

Two moderate positive correlations were identified between EC behaviors and actions. More precisely, Private Sphere Behaviors (PSB) were found to be correlated with National Scale Actions (NAS) $(r=0.54, p<0.01)$, whereas Other Behaviors (OB), indicating the indirect influence of individuals to the organizations they belong to and the consequent effects on the environment, were found to be linked with a moderate positive relation to Global Scale Actions (GSA) $(r=0.42, p<0.05)$.

\subsubsection{Correlations between the EC Competences and EEC Outcomes}

At our third step we aimed to reveal all possible strong and moderate correlations among the EC competences with the EEC outcomes. An overview of these correlations is presented in Figure 7 and further discussed in the following sub-sections.

\section{Correlations between EC Knowledge and EEC Outcomes}

According to the retrieved results on Spearman's rank correlations, Political Systems Knowledge (PSK) was found to be strongly associated with the Promotion of Inter/IntraGenerational Justice (IGJ) $(r=0.70, p<0.001)$. Furthermore, Action-Related Knowledge (ARK) was captured to be moderately related with the Prevention of New Environmental Problems (PNEP) $(\mathrm{r}=0.41, p<0.05)$, and the Solution of Environmental Problems (SEP) $(\mathrm{r}=0.46, p<0.01)$. 

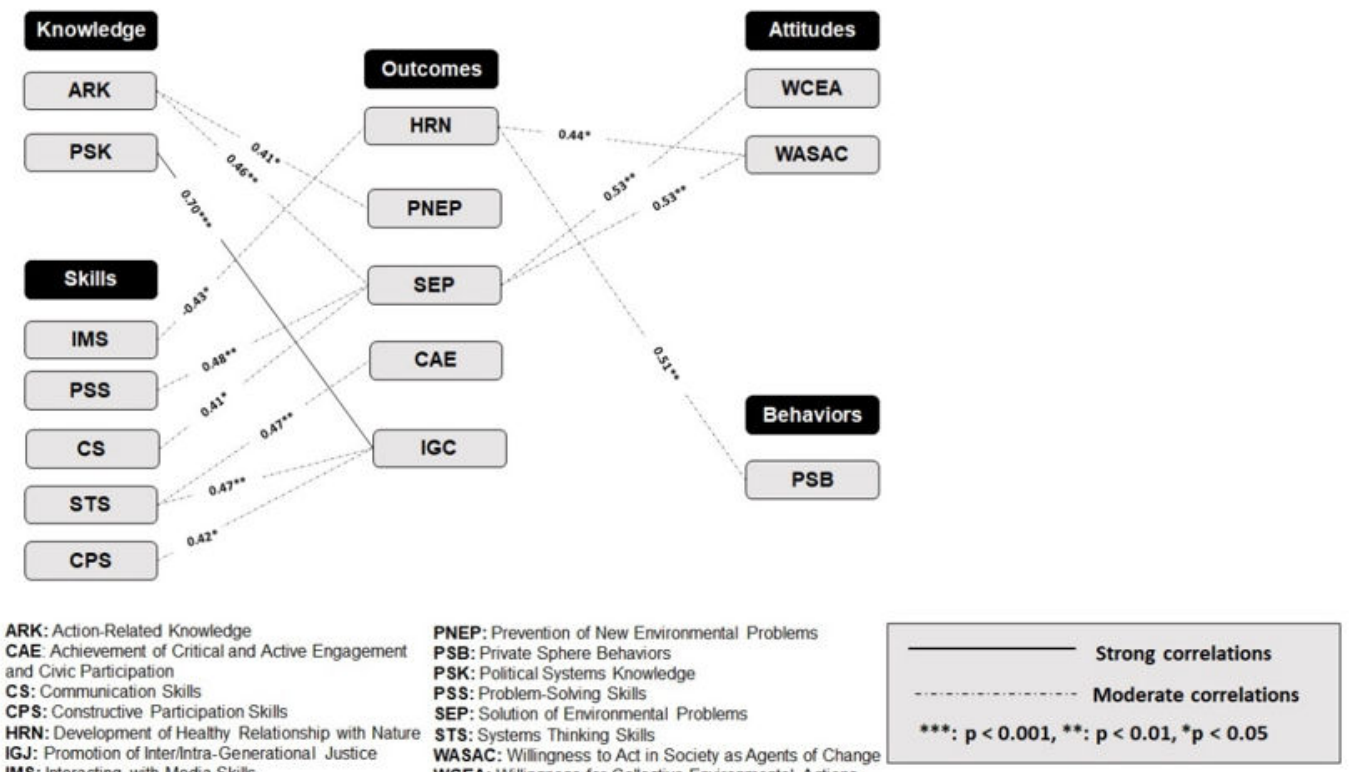

GJ: Promotion of Interintra-Generational Justice

STS: Systems Thinking Skills

WASAC: Willingness to Act in Society as Agents of Change

$* * *$ : $<<0.001, * *$ : $p<0.01, * p<0.05$

Figure 7. Correlations between the EC competences and EEC outcomes.

Correlations between EC Skills and Outcomes

According to the retrieved results on Spearman's rank correlations, it was found that both Problem-Solving Skills (PSS) and Communication Skills (CS) were positively linked to the Solution of Environmental Problems (SEP) with moderate correlations ( $\mathrm{r}=0.48, p<0.01$ and $r=0.41, p<0.05$, respectively). In addition, Systems Thinking Skills (STS) were identified to be moderately related to the Achievement of Critical and Active Engagement and Civic Participation (CAE) $(\mathrm{r}=0.47, p<0.01)$, and the Promotion of Inter/Intra-Generational Justice (IGJ) ( $\mathrm{r}=0.47, p<0.01)$; the latter was also found to be associated with Constructive Participation Skills (CPS) $(r=0.42, p<0.05)$. Worth noting is also the negative correlation observed between Interacting with Media Skills (IMS) and the Development of Healthy Relationship with Nature $(\mathrm{HRN})(\mathrm{r}=-0.43, p<0.05)$. This finding though is not surprising given that use of media and digital interfaces is often accused of disconnecting people from nature.

Correlations between EC Attitudes and EEC Outcomes

Statistically significant moderate correlations were identified between the Willingness to Act in Society as Agents of Change (WASAC) with the Solution of Environmental Problems (SEP) $(r=0.53, p<0.01)$, as well as with the Development of Healthy Relationship with Nature (HRN) $(r=0.44, p<0.05)$. Moreover, Willingness for Collective Environmental Actions (WCEA) was shown to be moderately associated to the Solution of Environmental Problems (SEP) $(\mathrm{r}=0.53, p<0.01)$.

Correlations between EC Behaviors and EEC Outcomes

One moderate positive correlation was observed between citizens' EC behaviors and environmental outcomes. In particular, Private Sphere Behaviors (PSB) were found to be positively related with the Development of a Healthy Relationship with Nature (HRN) $(\mathrm{r}=0.51, p<0.01)$.

\subsubsection{Interrelations between EC Actions and EEC Outcomes}

At our fourth and final step we aimed to reveal all possible strong and moderate correlations among the EC actions and EEC outcomes. An overview of these correlations is presented in Figure 8. 


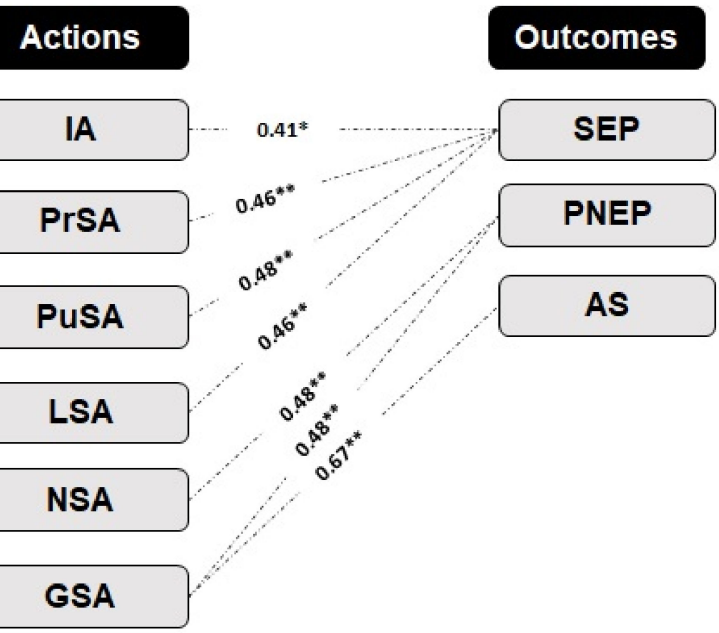

AS: Achievement of Sustainability

GSA: Global Scale Actions

IA: Individual Actions

LSA: Local Scale Actions

NSA: National Scale Actions

PNEP: Prevention of New Environmental Problems

PrSA: Private Sphere Actions

PuSA: Public Sphere Actions

SEP: Solution of Environmental Problems

Moderate correlations

$* *: p<0.01, * p<0.05$

Figure 8. Correlations between the EC actions and EEC outcomes.

According to our findings, the Solution of Environmental Problems (SEP) was found to be moderately related to Individual Actions (IA) $(r=0.41, p<0.05)$, Private Sphere Actions (PrSA) $(\mathrm{r}=0.46, p<0.01)$, Public Sphere Actions (PuSA) $(\mathrm{r}=0.48, p<0.01)$, as well as to Local Scale Actions (LSA) $(r=0.46, p<0.01)$. In addition, National Scale Actions (NSA) were found to be positively related to the Prevention of New Environmental Problems (PNEP) $(r=0.48, p<0.01)$. Finally, Global Scale Actions (GSA) were found to be positively related to the Achievement of Sustainability (AS) $(r=0.67, p<0.01)$ and, to a lesser extent, to the Prevention of New Environmental Problems (PNEP) $(r=0.48, p<0.01)$.

\subsection{RQ3: Which Are the More Salient Components from the EC Competences, Actions, and} EEC Outcomes?

As part of RQ3, we conducted a k-means cluster analysis to identify the most salient components (from the EC competences, EC actions, and EEC outcomes), taking into account their connections to the rest of the components, as these ones emerged in the context of the previously presented bivariate correlations (see Section 6.2). The k-means cluster analysis categorized the EC components in two homogenous groups (clusters): the Keystone Components group (KCs, $n=7 \mathrm{EC}$ components) which indicated a higher number of connections $(\bar{x}=7, \mathrm{SD}=1.73)$, and the Peripheral Components group (PCs, $n=41$ Components), which indicated a lower number of connections $(\overline{\mathrm{x}}=1.71, \mathrm{SD}=1.35)$ with the other EC components. This difference between the number of connections between the two groups was also statistically significant $(\mathrm{t}(48)=-9.23, p<0.001)$.

More specifically, as presented in Figure 9, we have identified seven KCs, as follows: Willingness to Act in Society as Agents of Change (WASAC) $(n=9$ connections), Solution of Environmental Problems (SEP) $(n=9$ connections), Political Systems Knowledge (PSK) ( $n=8$ connections), System Thinking Skills (STS) ( $n=7$ connections), Constructive Participation Skills (CPS) ( $n=6$ connections), Problem-Solving Skills (PSS) ( $n=5$ connections), and Local Scale Actions (LAS) ( $n=5$ connections). 


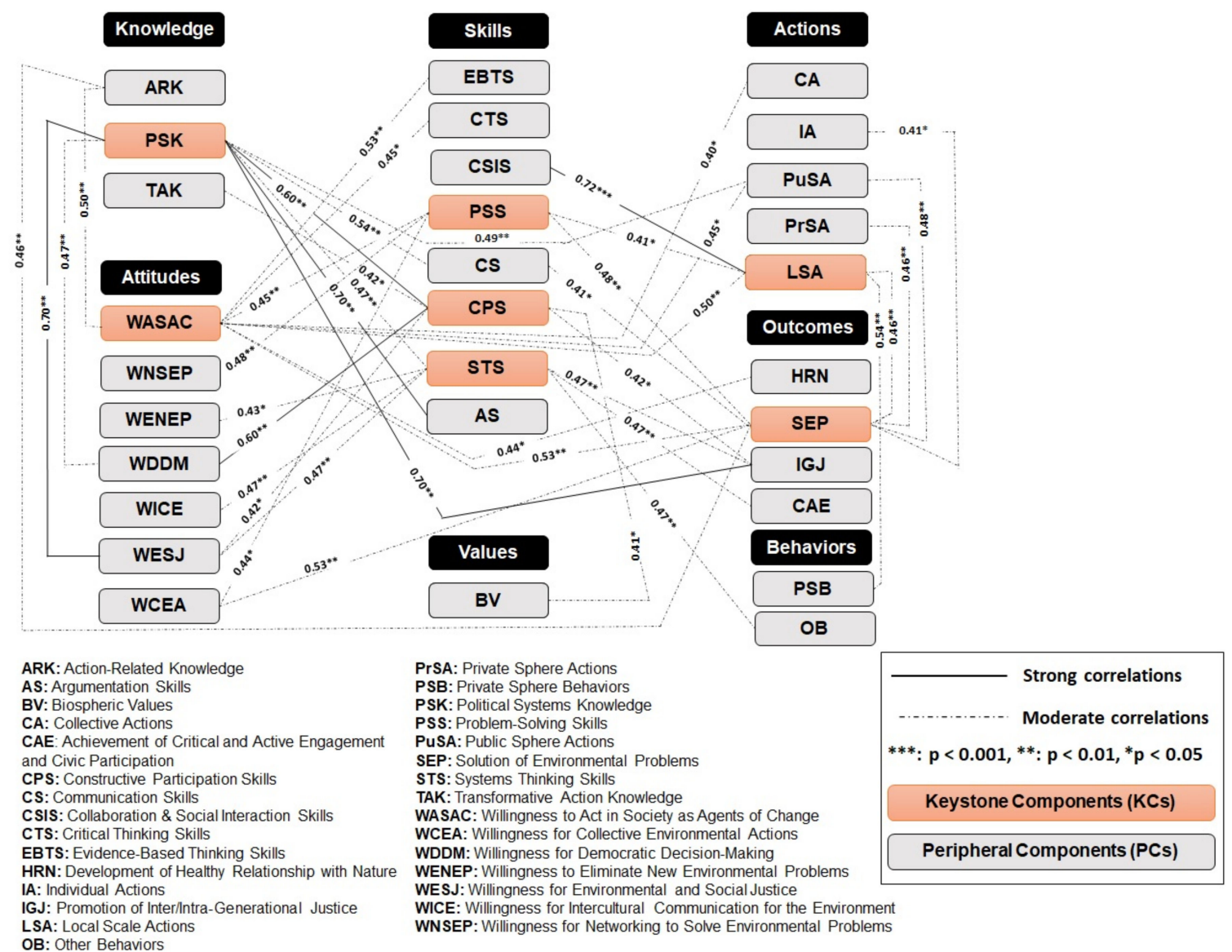

Figure 9. Correlations between the keystone components with the other EC components.

The first keystone component was Willingness to Act in Society as Agents of Change (WASAC), which was positively linked with a moderate correlation to Action-Related Knowledge (ARK) $(\mathrm{r}=0.50, p<0.01)$, Evidence-Based Thinking Skills (EBTS) $(\mathrm{r}=0.53$, $p<0.01)$, Critical Thinking Skills (CTS) $(\mathrm{r}=0.45, p<0.05)$, Problem-Solving Skills (PSS) $(\mathrm{r}=0.50, p<0.01)$, Collective Actions (CA) $(\mathrm{r}=0.40, p<0.05)$, Public Sphere Actions (PuSA) $(\mathrm{r}=0.45, p<0.05)$, Local Scale Actions (LSA) $(\mathrm{r}=0.50, p<0.01)$, Development of a Healthy Relationship with Nature (HRN) $(\mathrm{r}=0.44, p<0.05)$, and Solution of Environmental Problems (SEP) $(r=0.53, p<0.01)$.

The second keystone component was the Solution of Environmental Problems (SEP), which was positively linked with a moderate correlation to Action-Related Knowledge (ARK) $(r=0.46, p<0.01)$, Problem-Solving Skills (PSS) $(r=0.48, p<0.01)$, Communication Skills (CS) $(\mathrm{r}=0.41, p<0.05)$, Willingness for Collective Environmental Actions (WCEA) $(\mathrm{r}=0.53, p<0.01)$, Willingness to Act in Society as Agents of Change (WASAC) $(\mathrm{r}=0.53$, $p<0.01)$, Individual Actions (IA) $(r=0.41, p<0.05)$, Private Sphere Actions (PrSA) $(r=0.46$, $p<0.05)$, Public Sphere Actions (PuSA) $(\mathrm{r}=0.48, p<0.01)$, and Local Scale Actions (LSA) $(\mathrm{r}=0.46, p<0.01)$.

The third keystone component was Political Systems Knowledge (PSK), which was positively linked with a moderate correlation to Communication Skills (CS) ( $\mathrm{r}=054$, $p<0.01)$, System Thinking Skills (STS) $(r=0.47, p<0.01)$, Willingness for Democratic Decision-Making (WDDM) $(\mathrm{r}=0.47, p<0.01)$, and Public Sphere Actions (PuSA) $(\mathrm{r}=0.49$, $p<0.01$ ). In addition, Political Systems Knowledge (PSK) was positively linked with a strong correlation with Constructive Participation Skills (CPS) $(\mathrm{r}=0.60, p<0.01)$, Argumentation Skills (AS) $(\mathrm{r}=0.70, p<0.01)$, Willingness for Environmental and Social Justice (WESJ) $(\mathrm{r}=0.70, p<0.01)$, and the Promotion of Inter/Intra-Generational Justice (IGJ) $(\mathrm{r}=0.70, p<0.01)$. 
The fourth keystone component was Systems Thinking Skills (STS), which was positively linked with a moderate correlation to Political Systems Knowledge (PSK) $(r=0.47$, $p<0.01)$, Willingness for Environmental and Social Justice (WESJ) $(\mathrm{r}=0.47, p<0.01)$, Willingness for Intercultural Communication for the Environment (WICE) $(\mathrm{r}=0.47, p<0.01)$, Willingness to Eliminate New Environmental Problems (WENEP) $(r=0.43, p<0.05)$, Other Behaviors (OB) $(r=0.47, p<0.01)$, Achievement of Critical and Active Engagement and Civic Participation (CAE) $(\mathrm{r}=0.47, p<0.01)$, and Promotion of Inter/Intra-Generational Justice (IGJ) $(\mathrm{r}=0.47, p<0.01)$.

The fifth keystone component was Constructive Participation Skills (CPS), which was positively linked with a moderate correlation to Transformative Action Knowledge (TAK) $(\mathrm{r}=0.42, p<0.05)$, Biospheric Values (BV) $(\mathrm{r}=0.41, p<0.05)$, Willingness for Environmental and Social Justice (WESJ) ( $\mathrm{r}=0.42, p<0.05)$, Promotion of Inter/Intra-Generational Justice (IGJ) $(\mathrm{r}=0.42, p<0.01)$, and Willingness for Democratic Decision-Making (WDDM) $(\mathrm{r}=0.47$, $p<0.01)$. Constructive Participation Skills (CPS), were also positively linked with a strong correlation to Political Systems Knowledge (PSK) $(\mathrm{r}=0.60, p<0.01)$.

The sixth keystone component was the Problem-Solving Skills (PSS) which was positively linked with a moderate correlation to Willingness for Collective Environmental Actions (WCEA) $(\mathrm{r}=0.44, p<0.05)$, Willingness to Act in Society as Agents of Change (WASAC) $(\mathrm{r}=0.45, p<0.01)$, Willingness for Networking to Solve Environmental Problems (WNSEP) $(\mathrm{r}=0.48, p<0.01)$, Local Scale Actions (LSA) $(\mathrm{r}=0.41, p<0.05)$, and Solution of Environmental Problems (SEP) $(r=0.48, p<0.01)$.

Finally, the last keystone component was the Local Scale Actions (LSA) which was positively linked with a moderate correlation with Problem-Solving Skills (PSS) $(r=0.41$, $p<0.05)$, Private Sphere Behaviors (PSB) $(\mathrm{r}=0.54, p<0.01)$, Solution of Environmental Problems (SEP) $(\mathrm{r}=0.46, p<0.01)$, and Willingness to Act in Society as Agents of Change (WASAC) $(r=0.50, p<0.01)$. In addition, the Local Scale Actions (LSA) component was positively linked with a strong correlation with Collaboration and Social Interaction Skills (CSIS) $(\mathrm{r}=0.72, p<0.001)$.

\section{Discussion}

\subsection{Contribution to Citizens' EC Competences, EC Actions and EEC Outcomes}

According to our findings, the reviewed environmental CS initiatives contributed a great extent to the promotion of EC competences; however, we have also found that the reviewed environmental CS initiatives did not have an equal contribution to all the EC competences. We have found, for instance, that citizens' participation in the environmental CS initiatives had a mainly positive impact on their EC knowledge and skills. More specifically, our findings provide empirical substantiation on prior claims regarding CS initiatives' potential to promote scientific and ecological literacy, especially Environmental Systems Knowledge (ESK), which can deepen environmental connectedness [33-37]. Likewise, our findings are in agreement with prior research supporting that environmental CS initiatives contribute to the development of various inquiry-based and scientific skills, e.g., Evidence-Based Thinking Skills (EBTS), Problem-Solving Skills (PSS), Collaboration and Social Interaction Skills (CSIS), and Communication Skills (CS) [38,39]. However, we have also found that the reviewed environmental CS initiatives had a limited impact on other types of knowledge, such as Political Systems Knowledge (PSK) and Transformative Action Knowledge (TAK), as well as on skills such as Decision-Making Skills (DMS) and Argumentation Skills (AS), despite the significance of those in EC.

In addition, we have found that citizens' participation in environmental CS initiatives supported the enhancement of Biospheric Values (BV) to a significant degree. Likewise, our findings indicated that the reviewed CS initiatives had a positive impact on citizens' attitudes related to Willingness to Act in Society as Agents of Change (WASAC), Willingness for Collective Environmental Actions (WCEA), or Willingness to Eliminate New Environmental Problems (WENEP). However, attitudes related to Willingness for Environmental and Social Justice (WESJ), or Respect for Environmental Rights (RER) were addressed 
to a very limited degree or were not addressed at all. It should be noted, however, that the absence of these latter attitudes in the reviewed CS initiatives may be crucial for the development of environmentally responsible and active citizens, given that the degree of inclusiveness, the depth of democracy and participation, the issues of equality as well as the issues of intra- and inter-generational justice are of particular importance for the promotion of environmental citizenship, and for this reason are also situated into the core of EEC [17].

At the same time, it should be mentioned that, aligned with the prior research, our study confirms that the contribution of environmental CS initiatives to the enhancement of values, attitudes and pro-environmental behaviors was much more limited in comparison to their impact on citizens' environmental-related knowledge and skills [40]. Of course, this finding is not surprising, considering that, in most of the cases, citizens' participation in environmental CS initiatives seems to be relatively brief, while in addition to this, citizens' engagement is usually narrowed down to data collection processes [16]. This could provide a plausible explanation for the limited contribution of the reviewed CS initiatives to the enhancement of citizens' attitudes, values, and behaviors, which are deeply rooted in personality and need more time investment and concerted effort to be modified. Despite this fact, early enough, Dobson (2007) has supported that changing attitudes and values are crucial to cultivating environmental citizenship [41], whilst active involvement with environmental projects, such as environmental CS initiatives, should be deployed as an ideal venue to do so.

On a different note, our results have also shown that the EC actions supported by the reviewed environmental CS initiatives were mainly situated in the individual rather than in the collective dimension, as well as in the private rather than the public sphere. At the same time, we have identified that the EC actions, which were included in the reviewed environmental CS initiatives, were mostly situated at the local and national rather than at the global scale. This finding can be attributed to the dominant nature of environmental CS initiatives, given that in most of the cases, CS initiatives aim at establishing a local community connection, adopting a place-based approach, and as such, they prioritize local civic actions [16]. However, the multi-scalar environmental citizenship, as identified in the reviewed CS initiatives, should not be perceived as a drawback given that many environmental problems and their effects exist at global scales that require, at least initially, national or local community responsibility [18,42].

Finally, based on our results it seems that the contribution of environmental CS initiatives to the promotion of EC outcomes was much more limited in comparison to the promotion of EC actions and competences. In addition, we have found that the most reported environmental outcomes were the Solution of Environmental Problems (SEP), the Prevention of New Environmental Problems (PNEP), as well as the Development of a Healthy Relationship with the Nature (HRN). This latter finding is aligned with prior research, which supports how citizens involved in environmental management and conservation, biodiversity monitoring, and other nature-based activities included in environmental CS initiatives, tend to have a higher connectedness to nature than the average citizen [43,44]. However, our analysis has shown that environmental outcomes, such as the Promotion of Inter/Intra-Generational Justice (IGJ) or the Practice of Environmental Rights and Duties (ERD), were totally neglected. This reveals a significant gap, considering that EC involves an internal motivation of justice; what Hayward (2012) calls "embedded ecological justice" [45] (p.104).

\subsection{Correlations among the EC Competences, EC Actions, and EEC Outcomes in Environmental CS Initiatives}

As part of our review study, we have found a large number of strong and moderate correlations between the EC competences, EC actions, and EEC outcomes, in the context of the reviewed environmental CS initiatives. However, due to space limitations, in this section we will focus on and discuss only the strongest correlations, also taking into account their significance. 
To begin with, we have found strong correlations of Political Systems Knowledge (PSK) with Willingness for Environmental and Social Justice (WESJ), as well as with the Promotion of Inter/Intra-Generational Justice (IGJ). Knowledge has often been argued to play a crucial role in influencing pro-environmental behavior $[46,47]$. Following this reasoning, knowledge has been also assumed to play an essential role in promoting environmental citizenship; however, what remains unclear is what type of knowledge can contribute to the growth of environmental citizenship [48]. Socio-environmental justice as well as inter- and intra-generational justice are considered among the core components of Environmental Citizenship [17]. According to our findings, it seems that Political Systems Knowledge (PSK), as the knowledge about where authority lies, is related to issues of socio-environmental justice. This is not surprising as PSK can equip citizens with the knowledge needed to lobby authorities to achieve tangible environmental results and combat forms of inter- and intra-generational justice regarding current and prospect socio-environmental inequalities.

Secondly, we have found strong correlations of Political Systems Knowledge (PSK) with Argumentation Skills (AS) and Constructive Participation Skills (CPS). In addition, we have found that Constructive Participation Skills (CPS) were strongly correlated with Willingness for Democratic Decision-Making (WDDM). These correlations highlight the "civic" side of environmental citizenship, given that the successful participation of citizens in society as agents of change depends on the development of a person's knowledge and skills for a critical, active, and democratic engagement in preventing and solving environmental problems [49]. Put simply, to resolve environmental problems, citizens need to acquire skills and competencies, such as argumentation and decision-making skills, critical thinking, scientific or evidence-based thinking, and constructive participation skills $[50,51]$. Besides, the critical praxis of environmental citizenship implies elements of critical pedagogy [52] and "a capacity to critically examine and assess the complexities, patterns and politics that promulgate local and global environmental problems" [17] (p. 246).

Finally, we have found strong correlations of Collaboration and Social Interaction Skills (CSIS) with Willingness for Collective Environmental Actions (WCEA) and Local Scale Actions (LSA). These correlations emphasize the "social" and the "collective" nature of environmental citizenship given that, as posed by Hadjichambis and Reis (2020), environmental citizenship has collective action as an integral component, apart from personal actions in a private and public sphere [53]. Following this reasoning, Hadjichambis and Paraskeva-Hadjichambi have also argued that Education for Environmental Citizenship (EEC) "advocates a need to move beyond a central focus on individual attitudinal and Behavioral changes towards collectively building a better understanding of environmental learning processes aimed at socio-ecological change" [17] (p. 249). While this dimension of environmental citizenship has been often neglected in the context of environmental education, environmental CS initiatives could provide a fertile ground for this dimension to flourish, especially if they include more collaborative activities requiring a collective input from the participating citizens.

\subsection{The Most Salient Components from the EC Competences, EC Actions, and EEC Outcomes}

As part of this review study, we also aimed at unveiling the most salient components, from the EC competences, EC actions, and EEC outcomes. To do so, we focused on the number of connections between the EC components as these emerged in our bivariate correlation analysis, and we then conducted a k-means cluster analysis. In this way, the EC components were classified in two clusters, as follows: Keystone Components (KCs) with the greatest number of connections, and Peripheral Components (PCs) with a lower number of connections, with the rest of the EC components.

The first KC was Willingness to Act in Society as Agents of Change (WASAC), which was positively linked to nine of the EC components. This finding fits well with the core of EEC which integrates citizens' roles as agents of change, given that its ultimate goal is to transform citizens into catalysts for achieving sustainability in their local environment and beyond [17]. Environmental citizenship lies its ability to provide citizens the opportunity 
to participate in effecting positive change within their local communities, thereby allowing citizens to experience a higher "sense of their own agency and collective capacity" [54] (p. 192).

The second KC was Political Systems Knowledge (PSK) which was positively linked to seven of the EC components. This finding is crucial as it highlights the political dimensions of environmental citizenship and their importance. More specifically, as argued by Levinson et al. (2020), within a sustainable society people should be perceived as citizens with a political role, and as such "they need to understand those political structures which can be transformed through actions open to them for living in a sustainable environment" [55] (p. 25). Put simply, according to Hadjichambis and Reis 2020, individual citizens should be equipped with the knowledge needed in order be able to contribute to current environmental crisis through public pressures for political action (e.g., signing petitions, writing to politicians and newspapers) [53].

The third KC was Systems Thinking Skills (STS), which was positively linked to six of the EC components. This finding is not surprising given that in their milestone work on environmental citizenship, Berkowitz et al. (2005) have placed much emphasis on the understanding of key socio-ecological systems using sound ecological thinking, while also realizing the nature of ecological science and the role of humans within ecological systems and their interdependence with other organisms [51]. According to Paraskeva-Hadjichambi et al. (2020), "comprehending interdependence means understanding relationships-a shift in perception from focus on objects to focus on relationships and patterns in these relationships" [17] (p. 216). This type of perception is characteristic of systems thinking and plays a crucial role in achieving sustainability and education for sustainability [56].

The fourth KC was Constructive Participation Skills (CPS), which was positively linked to six of the EC components. Indeed, from a socioecological perspective, Regula Kyburz-Graber (2013) has claimed that educational approaches intended at involving citizens in environmental issues should be, among others, constructive by allowing people to participate in the construction of meaning and solutions [57]. In addition, Jackson et al. (2005) have argued that where values, risks and benefits are discussed between experts and stakeholders (e.g., at early stages of development of an innovative technology), all parties should be able to take part constructively [58]. Likewise, when it comes to environmental citizenship, citizens should be able to participate constructively in the public domain.

The fifth KC was Local Scale Actions (LAS), which was positively linked to five of the EC components. This finding is not surprising given that EC is mainly encouraged in the context of community- and place-based projects [20,59]. Likewise, environmental CS initiatives mainly adopt place-based approaches at a great degree aiming at the solution of local environmental issues [16]. However, CS initiatives should be also expanded in addressing socio-ecological challenges at national and global scales.

Last, the final two KCs were the Problem-Solving Skills (PSS) and Solution of Environmental Problems (SEP), which were positively linked to the rest of the EC components with a total of five and nine connections, respectively. Undoubtedly, for an environmental citizen, being able to address and contribute to the solution of current socio-ecological problems is vital. From an educational perspective, several researchers have argued for the importance of engaging both teachers and their students with a problem-solving process to address and find solutions to authentic environmental problems [60,61]. Put simply, as argued by Parra et al. (2020), Education for Environmental Citizenship "should therefore provide knowledge, skills and competences for real-world problem-solving processes in contexts of polycentric governance reaching from local to larger scale levels" [62] (p. 157).

Overall, the aforementioned KCs had a crucial role in structuring the maps (see Figures 5-8) presenting the main correlations among the EC components, as they were correlated to a significant number of these components (i.e., EC competences, EC actions and EEC outcomes). Just like the keystone species, which contribute to defining an entire ecosystem and without them, the ecosystem would be dramatically different or cease to 
exist altogether, the KCs that emerged in this study presented a similar value in structuring and holding together the "EC ecosystem".

\section{Conclusions}

Despite the prevailing scientific goals of CS to generate quality data [63], there is an increasing interest in understanding the impact of CS initiatives on participants themselves as well as on society $[33,64]$. Aligned with this direction, the present study has unveiled that environmental CS initiatives can contribute to Education for Environmental Citizenship (EEC), as a venue through which citizens can be active within their communities and beyond to achieve environmental sustainability.

Building on Irwin's call (1995) for linking science, citizens, and sustainability, our synthesis of existing research provided empirical substantiation on how citizens' participation in environmental CS initiatives can generate scientific knowledge about the environment, actively shape their own practices, and produce environmental action. More specifically, we have found that the reviewed CS initiatives have empowered citizens' personal and responsible environmental actions, which were mainly situated in the private sphere and at the local scale.

However, our findings have also indicated that the majority of the reviewed environmental CS initiatives primarily enhanced citizens' skills and knowledge over the competences of attitudes, values, and behaviors, as well as over actions and EEC outcomes. At the same time, our correlation analysis has brought to light a set of keystone components for EC; unfortunately, except for Solution of Environmental Problems (SEP) and Local Scale Actions (LAS), the rest of the keystone components, such as Willingness to Act in Society as Agents of Change (WASAC), Political Systems Knowledge (PSK), System Thinking Skills (STS), Constructive Participation Skills (CPS), and Problem-Solving Skills (PSS), were not supported to a great extent by the current forms of environmental CS initiatives. These findings may guide the future design of environmental CS initiatives, as according to Jørgensen and Jørgensen (2020), involvement in environmental CS activities can cultivate environmental citizenship, if CS initiatives are intentionally designed to do so [18].

\section{Limitations}

Even though the findings of this review study may help flesh out a more comprehensive picture regarding the relation of environmental CS initiatives with Education for Environmental Citizenship (EEC), this work has also some limitations. To start with, the use of search engines for retrieving scientific articles by filtering the available literature with specific keywords has risks and should be treated carefully to draw valid conclusions [65]. More specifically, our approach resulted in the review of academic articles in the English language within the last two decades (2000-2020), without covering other languages. However, the filtering of studies according to time of publication and English language might lead to chronological and geographic exclusion of other relevant work in the field [66]. At the same time, the fact that our review included only 31 empirical studies could be perceived as another limitation.

\section{Future Directions}

Despite the aforementioned limitations, in our review study we have proceeded on a thorough statistical analysis of the available empirical data, and our findings can guide future research in the field of environmental CS initiatives in various ways. Profoundly, environmental CS initiatives should integrate the EC competences, EC actions and EEC outcomes of the EEC model at a much greater degree; in this way, the "citizen" dimension in "citizen" science initiatives will be empowered and promoted, as needed. More specifically, future environmental CS initiatives should provide more emphasis on the development of the EC competences and in particular of attitudes, values, and behaviors. For instance, attitudes related to Willingness for Environmental and Social Justice (WESJ) or Respect for Environmental Rights (RER) should be addressed, taking into account that they are of 
crucial significance in the context of EC. Secondly, even though the reviewed environmental CS initiatives seem to promote mostly the EC competences of knowledge and skills, we have found that several EC skills and knowledge were neglected. In this context, future environmental CS initiatives should pay more attention to the promotion of other types of knowledge, such as Political Systems Knowledge (PSK) and Transformative Action Knowledge (TAK) as well as on other skills, such as Decision-Making Skills (DMS) and Argumentation Skills (AS). Thirdly, our findings urge the need for expanding the nature and type of CS initiatives to also include EC actions, such as collective and public actions, as these can deepen even more the notion of environmental citizenship. Fourthly, while we have found that the majority of environmental CS initiatives adopted a place-based approach and were narrowed down to the promotion of local scale actions; future CS initiatives should be expanded towards the promotion of EC actions situated at the national and global scales. Finally, according to our findings, when it comes to the EEC outcomes, it seems that future environmental CS initiatives should place more emphasis on inter/intragenerational justice as well as on the empowerment of practicing environmental rights and duties. Overall, as argued by Stuhmcke et al. (2012) environmental CS initiatives should be designed in a way that expands citizens' participation from mere data collection activities in the process of decision-making regarding crucial socio-environmental issues, as well as in the following action-taking oriented towards environmental and social change [67]. When this occurs, then more fertile ground will be available for environmental citizenship to flourish in the context of environmental CS initiatives.

Supplementary Materials: The following are available online at https:/ / www.mdpi.com/article / 10.3390/su132413692/su132413692/s1, Table S1: Definitions and indicative excerpts of the coding scheme, S2: Reviewed articles.

Author Contributions: Conceptualization, A.C.H. and D.P.-H.; methodology, A.A., Y.G., D.P.-H. and A.C.H.; software, A.A. and Y.G.; validation, D.P.-H. and A.C.H.; formal analysis, A.C.H.; investigation, A.A. and Y.G.; resources, A.A., Y.G., D.P.-H. and A.C.H.; data curation, A.A., Y.G. and D.P.-H.; writing—original draft preparation, A.A.; writing—review and editing, Y.G., D.P.-H. and A.C.H.; visualization, A.C.H. and D.P.-H.; supervision, A.C.H. and D.P.-H.; project administration, A.A.; funding acquisition, A.C.H. and D.P.-H. All authors have read and agreed to the published version of the manuscript.

Funding: This research was funded by EnviroCitizen Project. The EnviroCitizen project has received funding from the European Union's Horizon 2020 research and innovation programme under grant agreement No 872557.

Institutional Review Board Statement: Not applicable.

Informed Consent Statement: Not applicable.

Data Availability Statement: No new data were created or analyzed in this study. Data sharing is not applicable to this article.

Acknowledgments: This study is partly inspired by the ENEC Cost Action -European Networks for Environmental Citizenship-CA16229 supported by COST (European Cooperation in Science and Technology-Horizon 2020).

Conflicts of Interest: The authors declare no conflict of interest.

\section{References}

1. Millennium Ecosystem Assessment. Ecosystems and Human Well-Being: Biodiversity Synthesis; World Resources Institute: Washington, DC, USA, 2005.

2. Irwin, A. Citizen Science A Study of People, Expertise and Sustainable Development, 1st ed.; Psychology Press: Hove, UK, 1995. [CrossRef]

3. Pettibone, L.; Vohland, K.; Ziegler, D. Understanding the (inter)disciplinary and institutional diversity of citizen science: A survey of current practice in Germany and Austria. PLoS ONE 2017, 12, 1-16. [CrossRef]

4. Tulloch, A.I.T.; Possingham, H.P.; Joseph, L.N.; Szabo, J.; Martin, T.G. Realising the full potential of citizen science monitoring programs. Biol. Conserv. 2013, 165, 128-138. [CrossRef] 
5. Shirk, J.L.; Bonney, R. Citizen Science Framework Review: Informing a Framework for Citizen Science within the US Fish and Wildlife Service; Cornell Lab of Ornithology: Ithaca, NY, USA, 2015.

6. Hecker, S.; Haklay, M.; Bowser, A.; Makuch, Z.; Johannes, V.; Boon, A. Citizen Science: Innovation in Open Science, Society and Policy; UCL Press: London, UK, 2018; Available online: http://www.jstor.org/stable/j.ctv550cf2 (accessed on 30 October 2021).

7. McKinley, D.C.; Miller-Rushing, A.J.; Ballard, H.L.; Bonney, R.; Brown, H.; Cook-Patton, S.C.; Evans, D.M.; French, R.A.; Parrish, J.K.; Phillips, T.B.; et al. Citizen science can improve conservation science, natural resource management, and environmental protection. Biol. Conserv. 2017, 208, 15-28. [CrossRef]

8. Pocock, M.J.O.; Roy, H.E.; August, T.; Kuria, A.; Barasa, F.; Bett, J.; Githiru, M.; Kairo, J.; Kimani, J.; Kinuthia, W.; et al. Developing the global potential of citizen science: Assessing opportunities that benefit people, society and the environment in East Africa. J. Appl. Ecol. 2019, 56, 274-281. [CrossRef]

9. Bonney, R.; Cooper, C.B.; Dickinson, J.; Kelling, S.; Phillips, T.; Rosenberg, K.V.; Shirk, J. Citizen science: A developing tool for expanding science knowledge and scientific literacy. BioScience 2009, 59, 977-984. [CrossRef]

10. Johnson, M.F.; Hannah, C.; Acton, L.; Popovici, R.; Karanth, K.K.; Weinthal, E. Network environmentalism: Citizen scientists as agents for environmental advocacy. Glob. Environ. Chang. 2014, 29, 235-245. [CrossRef]

11. Chandler, M.; See, L.; Copas, K.; Bonde, A.M.Z.; López, B.C.; Danielsen, F.; Legind, J.K.; Masinde, S.; Miller-Rushing, A.J.; Newman, G.; et al. Contribution of citizen science towards international biodiversity monitoring. Biol. Conserv. 2017, 213, 280-294. [CrossRef]

12. Kelly, R.; Fleming, A.; Pecl, G.T.; Von Gönner, J.; Bonn, A. Citizen science and marine conservation: A global review: Citizen science and marine conservation. Philos. Trans. R. Soc. B Biol. Sci. 2020, 375, 20190461. [CrossRef] [PubMed]

13. Pandya, R.; Dibner, K.A. Learning through citizen science: Enhancing opportunities by design. In Learning Through Citizen Science: Enhancing Opportunities by Design; The National Academies Press: Washington, DC, USA, 2019. [CrossRef]

14. Shirk, J.L.; Ballard, H.L.; Wilderman, C.C.; Phillips, T.; Wiggins, A.; Jordan, R.; McCallie, E.; Minarchek, M.; Lewenstein, B.V.; Krasny, M.E.; et al. Public participation in scientific research: A framework for deliberate design. Ecol. Soc. 2012, 17, 29. [CrossRef]

15. Turrini, T.; Dörler, D.; Richter, A.; Heigl, F.; Bonn, A. The threefold potential of environmental citizen science-Generating knowledge, creating learning opportunities and enabling civic participation. Biol. Conserv. 2018, 225, 176-186. [CrossRef]

16. Vasiliades, M.A.; Hadjichambis, A.C.; Paraskeva-Hadjichambi, D.; Adamou, A.; Georgiou, Y. A Systematic Literature Review on the Participation Aspects of Environmental and Nature-Based Citizen Science Initiatives. Sustainability 2021, 13, 7457. [CrossRef]

17. Hadjichambis, A.C.; Paraskeva-Hadjichambi, D. Education for Environmental Citizenship: The Pedagogical Approach. In Conceptualizing Environmental Citizenship for 21st Century Education; Environmental Discourses in Science Education; Hadjichambis, A.C., Reis, P., Paraskeva-Hadjichambi, D., Činčera, J., Boeve-de Pauw, J., Gericke, N., Knippels, M.-C., Eds.; Springer: Cham, Switzerland, 2020; Volume 4, pp. 237-261. [CrossRef]

18. Jørgensen, F.A.; Jørgensen, D. Citizen science for environmental citizenship. Conserv. Biol. 2020, 35, 1-4. [CrossRef]

19. Tsybulsky, D. Self-Reported Reasons for Participating in Pro-environmental Citizen Science Activities: A Case Study of Butterfly Monitoring in Israel. Front. Educ. 2020, 5, 116. [CrossRef]

20. Georgiou, Y.; Hadjichambis, A.C.; Hadjichambi, D. Teachers' perceptions on environmental citizenship: A systematic review of the literature. Sustainability 2021, 13, 2622. [CrossRef]

21. Monte, T.; Reis, P. Design of a pedagogical model of education for environmental citizenship in primary education. Sustainability 2021, 13, 6000. [CrossRef]

22. Jordan, R.C.; Gray, S.A.; Howe, D.V.; Brooks, W.R.; Ehrenfeld, J.G. Knowledge Gain and Behavioral Change in Citizen-Science Programs. Conserv. Biol. 2011, 25, 1148-1154. [CrossRef]

23. Chao, S.H.; Jiang, J.Z.; Wei, K.C.; Ng, E.; Hsu, C.H.; Te, Y.C.; Fang, W.T.W. Understanding pro-environmental behavior of citizen science: An exploratory study of the bird survey in Taoyuan's farm ponds project. Sustainability 2021, 13, 5126. [CrossRef]

24. Pierini, V.I.; Mazzeo, N.; Cazenave, M.; Semmartin, M. Waste generation and pro-environmental behaviors at household level: A citizen science study in Buenos Aires (Argentina). Resour. Conserv. Recycl. 2021, 170, 105560. [CrossRef]

25. Santori, C.; Keith, R.J.; Whittington, C.M.; Thompson, M.B.; Van Dyke, J.U.; Spencer, R.J. Changes in participant behavior and attitudes are associated with knowledge and skills gained by using a turtle conservation citizen science app. People Nat. 2021, 3, 66-76. [CrossRef]

26. Frick, J.; Kaiser, F.G.; Wilson, M. Environmental knowledge and conservation behavior: Exploring prevalence and structure in a representative sample. Personal. Individ. Differ. 2004, 37, 1597-1613. [CrossRef]

27. Johnson, L.; Morris, P. Towards a framework for critical citizenship education. Curric. J. 2010, 21, 77-96. [CrossRef]

28. The Council of the European Union. Council recommendation of 22 May 2018 on key competences for lifelong learning (text with EEA relevance). Off. J. Eur. Union 2018, 1, 1-13. Available online: https:/ / eur-lex.europa.eu/legal-content/EN/TXT/PDF/?uri= CELEX:32018H0604(01)\&from=EN (accessed on 10 September 2021).

29. Bouman, T.; Steg, L.; Kiers, H. Measuring Values in Environmental Research: A Test of an Environmental Portrait Value Questionnaire. Front. Psychol. 2018, 9, 564. [CrossRef]

30. Stern, P.C. Toward a coherent theory of environmentally significant behavior. J. Soc. Issues 2000, 56, 407-424. [CrossRef]

31. Evans, J.D. Straightforward Statistics for the Behavioral Sciences; Thomson Brooks/Cole Publishing: Pacific Grove, CA, USA, 1996.

32. Han, J.; Kamber, M.; Pei, J. Data Mining: Concepts and Techniques; Elsevier: Amsterdam, The Netherlands, 2011. 
33. Bela, G.; Peltola, T.; Young, J.C.; Balázs, B.; Arpin, I.; Pataki, G.; Bonn, A. Learning and the transformative potential of citizen science. Conserv. Biol. 2016, 30, 990-999. [CrossRef]

34. Haywood, B.K. Beyond Data Points and Research Contributions: The Personal Meaning and Value Associated with Public Participation in Scientific Research. Int. J. Sci. Educ. Part B Commun. Public Engagem. 2016, 6, 239-262. [CrossRef]

35. McGreavy, B.; Calhoun, A.J.K.; Jansujwicz, J.; Levesque, V. Citizen science and natural resource governance: Program design for vernal pool policy innovation. Ecol. Soc. 2016, 21, 48. [CrossRef]

36. Crall, A.W.; Newman, G.J.; Stohlgren, T.J.; Holfelder, K.A.; Graham, J.; Waller, D.M. Assessing citizen science data quality: An invasive species case study. Conserv. Lett. 2011, 4, 433-442. [CrossRef]

37. Brossard, D.; Lewenstein, B.; Bonney, R. Scientific knowledge and attitude change: The impact of a citizen science project. Int. J. Sci. Educ. 2005, 27, 1099-1121. [CrossRef]

38. Peter, M.; Diekötter, T.; Kremer, K. Participant outcomes of biodiversity citizen science projects: A systematic literature review. Sustainability 2019, 11, 2780. [CrossRef]

39. Phillips, T.; Porticella, N.; Constas, M.; Bonney, R. A Framework for Articulating and Measuring Individual Learning Outcomes from Participation in Citizen Science. Citiz. Sci. Theory Pract. 2018, 3, 3. [CrossRef]

40. Kenyon, E.; Christoff, A.; Wisdom, S. Citizen science: Expanding ideas of citizenship and science. Soc. Stud. Res. Pract. 2020, 15, 83-96. [CrossRef]

41. Dobson, A. Environmental citizenship: Towards sustainable development. Sustain. Dev. 2007, 15, 276-285. [CrossRef]

42. Valencia Sáiz, Á. Globalisation, cosmopolitanism and ecological citizenship. Environ. Politics 2005, 14, 163-178. [CrossRef]

43. Ganzevoort, W.; van den Born, R. The thrill of discovery: Significant nature experiences among biodiversity citizen scientists. Ecopsychology 2019, 11, 22-32. [CrossRef]

44. Evans, C.; Abrams, E.; Reitsma, R.; Roux, K.; Salmonsen, L.; Marra, P.P. The Neighborhood Nestwatch program: Participant outcomes of a citizen-science ecological research project. Conserv. Biol. 2005, 19, 589-594. [CrossRef]

45. Hayward, B. Children, Citizenship and Environment: Nurturing a Democratic Imagination in a Changing World; Routledge: Abingdonon-Thames, UK, 2012.

46. Latif, S.A.; Omar, M.S.; Bidin, Y.H.; Awang, Z. Role of environmental knowledge in creating pro-environmental residents. Procedia Soc. Behav. Sci. 2013, 105, 866-874. [CrossRef]

47. Liobikienè, G.; Poškus, M.S. The importance of environmental knowledge for private and public sphere pro-environmental behavior: Modifying the Value-Belief-Norm theory. Sustainability 2019, 11, 3324. [CrossRef]

48. Smederevac-Lalic, M.; Finger, D.; Kovách, I.; Lenhardt, M.; Petrovic, J.; Djikanovic, V.; Boeve-de Pauw, J. Knowledge and Environmental Citizenship. In Conceptualizing Environmental Citizenship for 21st Century Education; Environmental Discourses in Science Education; Hadjichambis, A.C., Reis, P., Paraskeva-Hadjichambi, D., Činčera, J., Boeve-de Pauw, J., Gericke, N., Knippels, M.-C., Eds.; Springer: Cham, Switzerland, 2020; Volume 4, pp. 69-82. [CrossRef]

49. Reis, P. Environmental citizenship and youth activism. In Conceptualizing Environmental Citizenship for 21st Century Education; Environmental Discourses in Science Education; Hadjichambis, A.C., Reis, P., Paraskeva-Hadjichambi, D., Činčera, J., Boeve-de Pauw, J., Gericke, N., Knippels, M.-C., Eds.; Springer: Cham, Switzerland, 2020; Volume 4, pp. 139-148. [CrossRef]

50. Schusler, T.M.; Krasny, M.E.; Peters, S.J.; Decker, D.J. Developing citizens and communities through youth environmental action. Environ. Educ. Res. 2009, 15, 111-127. [CrossRef]

51. Berkowitz, A.R.; Ford, M.E.; Brewer, C.A. A framework for integrating ecological literacy, civics literacy, and environmental citizenship in environmental education. In Environmental Education and Advocacy: Changing Perspectives of Ecology E Education; Cambridge University Press: Cambridge, UK, 2005.

52. Freire, P. Pedagogia do Oprimido (Pedagogy of the Oppressed); Paz e Terra: Rio de Janeiro, Brazil, 1987.

53. Hadjichambis, A.; Reis, P. Introduction to the conceptualisation of environmental citizenship for twenty-first-century education. In Conceptualizing Environmental Citizenship for 21st Century Education; Environmental Discourses in Science Education; Hadjichambis, A.C., Reis, P., Paraskeva-Hadjichambi, D., Činčera, J., Boeve-de Pauw, J., Gericke, N., Knippels, M.-C., Eds.; Springer: Cham, Switzerland, 2020; Volume 4, pp. 1-14. [CrossRef]

54. Smith, G.A. Place-based education: Breaking through the constraining regularities of public school. Environ. Educ. Res. 2007, 13, 189-207. [CrossRef]

55. Levinson, R.; Paraskeva-Hadjichambi, D.; Bedsted, B.; Manov, B.; Hadjichambis, A. Political Dimensions of Environmental Citizenship. In Conceptualizing Environmental Citizenship for 21st Century Education; Environmental Discourses in Science Education; Hadjichambis, A.C., Reis, P., Paraskeva-Hadjichambi, D., Činčera, J., Boeve-de Pauw, J., Gericke, N., Knippels, M.-C., Eds.; Springer: Cham, Switzerland, 2020; Volume 4, pp. 17-28. [CrossRef]

56. Capra, F. The Web of Life: A New Scientific Understanding of Living Systems; Anchor: New York, NY, USA, 1997.

57. Kyburz-Graber, R. 3 Socioecological Approaches to Environmental Education and Research: A Paradigmatic Response to Behavioral Change Orientations. In International Handbook of Research on Environmental Education; Routledge: Abingdon-onThames, UK, 2013; pp. 23-32.

58. Jackson, R.; Barbagallo, F.; Haste, H. Strengths of public dialogue on science-related issues. Crit. Rev. Int. Soc. Political Philos. 2005, 8, 349-358. [CrossRef]

59. Goldman, D.; Hansmann, R.; Činčera, J.; Radović, V.; Telešienė, A.; Balžekienė, A.; Vávra, J. Education for environmental citizenship and responsible environmental Behavior. In Conceptualizing Environmental Citizenship for 21st Century Education; 
Environmental Discourses in Science Education; Hadjichambis, A.C., Reis, P., Paraskeva-Hadjichambi, D., Činčera, J., Boeve-de Pauw, J., Gericke, N., Knippels, M.-C., Eds.; Springer: Cham, Switzerland, 2020; Volume 4, pp. 115-137. [CrossRef]

60. Effeney, G.; Davis, J. Education for sustainability: A case study of pre-service primary teachers' knowledge and efficacy. Aust. J. Teach. Educ. 2013, 38, 32-46. [CrossRef]

61. Desjean-Perrotta, B.; Moseley, C.; Cantu, L.E. Preservice teachers' perceptions of the environment: Does ethnicity or dominant residential experience matter? J. Environ. Educ. 2008, 39, 21-32. [CrossRef]

62. Parra, G.; Hansmann, R.; Hadjichambis, A.C.; Goldman, D.; Paraskeva-Hadjichambi, D.; Sund, P.; Sund, L.; Gericke, N.; Conti, D. Education for Environmental Citizenship and Education for Sustainability. In Conceptualizing Environmental Citizenship for 21st Century Education; Environmental Discourses in Science Education; Hadjichambis, A.C., Reis, P., Paraskeva-Hadjichambi, D., Činčera, J., Boeve-de Pauw, J., Gericke, N., Knippels, M.-C., Eds.; Springer: Cham, Switzerland, 2020; Volume 4, pp. 149-160. [CrossRef]

63. Bonney, R.; Ballard, H.; Jordan, R.; McCallie, E.; Phillips, T.; Shirk, J.; Wilderman, C.C. Public Participation in Scientific Research: Defining the Field and Assessing Its Potential for Informal Science Education A CAISE Inquiry Group Report; Center for Advancement of Informal Science Education (CAISE): Washington, DC, USA, 2009.

64. Schaefer, T.; Kieslinger, B.; Brandt, M.; van den Bogaert, V. Evaluation in Citizen Science: The Art of Tracing a Moving Target. In The Science of Citizen Science; Springer: Cham, Switzerland, 2021; pp. 495-514.

65. Mingers, J.; Leydesdorff, L. A review of theory and practice in scientometrics. Eur. J. Oper. Res. 2015, 246, 1-19. [CrossRef]

66. Mongeon, P.; Paul-Hus, A. The journal coverage of Web of Science and Scopus: A comparative analysis. Scientometrics 2016, 106, 213-228. [CrossRef]

67. Stuhmcke, S.M. Children as Change Agents for Sustainability: An Action Research Case Study in a Kindergarten. Ph.D. Dissertation, Queensland University of Technology, Brisbane, Australia, 2012. 